\title{
MinOR Discrepancies: Forging A COMMON UNDERSTANDING OF Adolescent CoMPETENCE IN HealthCare Decision-Making AND CRIMINAL Responsibility
}

\author{
Kimberly M. Mutcherson*
}

\section{INTRODUCTION}

IF TEENAGERS ARE ACCORDED AUTONOMY RIGHTS ON THE ASSUMPTION THAT THEY ARE CAPABLE OF MAKING CHOICES AS WELL AS ADULTS, THEN PERHAPS THERE IS LITTLE JUSTIFICATION FOR A SEPARATE JUVENILE JUSTICE SYSTEM. AND CONVERSELY, IF AN ADOLESCENT'S CHOICE TO COMMIT A CRIME SHOULD BE "RESPECTED” BY SUBJECTING IT TO THE SAME TREATMENT GIVEN AN ADULT'S DECISION, THERE IS LITTLE JUSTIFICATION FOR DENYING AUTONOMY RIGHTS TO TEENAGERS IN OTHER LEGAL CONTEXTS. ${ }^{1}$

In the recent past, several young people convicted of capital crimes received life-term sentences in adult prisons or even the death penalty-punishments that seem incompatible with the young age of the defendants. When a fifteen-year-old commits a serious crime for which adult punishment is possible, many juvenile justice advocates decry the use of the adult penal system to contend with "children" too immature to consider the ramifications of their actions before committing their crimes. These advocates raise concerns about adolescent impulsiveness, the pull of peer pressure and, in more recent times, point to research on the still growing adolescent brain to justify their view that the law should not treat juveniles as adults when meting out justice. Those who argue against such harsh penalties for young people do so, at least in part, based on a belief in adolescent decisional incapacity. In other words, young people lack the decision-making ability necessary to justify imposing adult sentences upon them even for the most heinous crimes.

By contrast, when faced with a pregnant fifteen-year-old seeking to access abortion services or prenatal care, some advocates for young people in the

* Associate Professor, Rutgers School of Law-Camden. My thanks to Rand Rosenblatt and Ann Freedman for their assistance in thinking through the ideas in this paper and to Sally Goldfarb and Kim Ferzan for their extremely helpful critique of early drafts. Rebecca Dippner provided much needed, rapid research assistance during a very hectic time, and I sincerely appreciate her hard work. As always, I am grateful to Samantha for giving me time to work and to Max for being such a great distraction.

1 Donald L. Beschle, The Juvenile Justice Counterrevolution: Responding To Cognitive Dissonance In The Law's View Of The Decision-Making Capacity of Minors, 48 EMORY L.J. 65,68 (1999). 
healthcare decision-making arena argue that adolescents do posses the maturity and competence to reason through options and make critical healthcare decisions without the knowledge or consent of parents. On this end of the spectrum, advocates seek enhanced decision-making rights for adolescents by claiming that most adolescents are in fact developmentally capable of meaningfully participating in and even independently directing their own healthcare. Advocates have made this argument particularly strenuously in the context of abortion rights for young women though it also appears in other healthcare contexts.

Given these potentially clashing views of adolescent decision-making capacity, it is possible that advocates for juveniles in these two areas of law undermine each other's causes and are at serious odds with each other. This seeming divide between people who claim allegiance to and concern for young people and who may, in fact, believe deeply in the other's cause marks two groups of advocates for young people who are on divergent paths. Juvenile justice advocates march toward a future in which the criminal justice system, with few exceptions, consistently presumes adolescent developmental deficiencies significant enough to protect young defendants from much criminal responsibility and certainly sufficient to protect young people from prosecution and punishment as adults. At the same time, many healthcare advocates march toward an opposite future in which those in the healthcare system presume adolescent developmental capacity also with few exceptions.

In the quest for a unified and all-encompassing legal regime governing adolescents across areas of law, one might simply choose one understanding of general adolescent competence or incompetence and apply it across the board. Arguably, a unified vision is a worthwhile goal if it replaces the present patchwork of common and statutory law dealing directly or indirectly with questions of competence and young people. However, embracing one view of the developmental capacity of adolescents seems to preclude embracing the other. In choosing a single position, one fears that adolescents will be left unduly vulnerable either in the criminal courts or in the offices of their healthcare providers.

This article seeks to understand the divide between groups of advocates and stake out a compromise position that supports an integrated system of measuring adolescent competence across different areas of the law. Ultimately, I conclude that there is an underlying consistency in these different views of adolescent competence or decision-making capacity. Therefore, they can peacefully coincide and be reconciled so that the assertion of one position does not diminish the claim of the other.

When speaking to each other, juvenile justice advocates and healthcare advocates have little trouble embracing each other's positions on adolescent competence and perceive no lapse in logic in their claims. My concern, however, is with a wider audience of judges and policymakers who remain unconvinced that one can make claims of both competence and incompetence in the same breath. Rather than preaching to the converted, this article seeks to create a few more converts and begins with the assumption that advocates for young people, in whatever field, must explain their embrace of the fluctuating nature of competence such that the same young person can be competent in one realm and concurrently incompetent in another. This concept of elasticity seems quite 
intuitive, but is too frequently masked in discussions that leave a reader with an impression of competence as a rigid construct.

Part I discusses various ways of understanding competence and decisionmaking capacity for adolescents. This section illustrates that the core elements of these concepts are the same when deployed by juvenile justice advocates or those debating healthcare decision-making rights for young people.

Part II delineates how advocates in the healthcare arena have articulated their belief in wide adolescent decision-making competence in this realm with a specific focus on abortion. The section concludes with a discussion of Supreme Court jurisprudence.

Part III shifts focus to describe how different parties have discussed issues of adolescent development and competence in the criminal context. It concludes with a discussion of how the Supreme Court has confronted this issue.

Part IV queries whether there is in fact a divide between the two articulated positions of adolescent competence. The section describes the pros and cons of creating a unified vision of adolescents for purposes of configuring them in the law. This section then works to reconcile the two positions by acknowledging the complexity of the inquiry and exploring the possibility that contrasting views of adolescent competence in different contexts are in fact quite compatible. I argue that the milieu in which young people make decisions, i.e., in formal versus informal settings, demonstrably affects the quality of the decision-making process. As such, it is logical to conclude that the decision-making process in formal healthcare settings leads to better decisions that the law should support than is the case in the informal settings in which young people decide to participate in criminal activities. As such, any presumptions of decisional-capacity and responsibility for those decisions can and should be different in the healthcare arena versus the criminal arena.

\section{Understanding the Concept of Competence}

This section grounds the remaining discussion in this article by defining the terms competence and decision-making capacity as used in this piece. In a quest to understand any potential conflict between advocates and to dictate a compromise position between polarized opinions, it is first necessary to detail how healthcare advocates and juvenile justice advocates understand the concepts of competence and decision-making capacity.

As an initial matter, one must ascertain whether advocates on both sides of the adolescent competence discussion mean the same thing when they refer to a minor's ${ }^{2}$ competence. Defining competence is a difficult task in part because

2 Throughout this piece, I use the terms juvenile, adolescent, and minor interchangeably to refer to those under the age of eighteen. As a myriad of state statutes make clear, the age of eighteen has great legal significance and generally marks the dividing line between childhood and adulthood for purposes of legal rights and responsibilities, including the right to vote or serve on a jury. This is not to say that there are no other significant birthdays along the path to legal adulthood. For instance, the legal drinking age in the states is twenty-one. See, e.g., Ala. Code \$ 28-1-5 (2003); Ariz. Rev. Stat. \$ 4-101 (2004); Colo. Rev. Stat. $\S 12-47-901$ (2003); Fla. STAT. $\$ 562.11$ (2003). With some restrictions, young people can earn a driver's license upon turning sixteen. See, e.g., Alaska Stat. § 28.15.055 (Michie 2003); Md. Code AnN., Transp. I § 16-103 (2001); Mich. Comp. Laws AnN. $\$ 257.308$ 
the concept does not lend itself to simple definitions. It has been described as "the ability to 'perform a task,' entailing the capacity to understand information, deliberate, and decide." 3 The definitional difficulty is heightened by the fact that this slippery concept exists across a broad spectrum of discussions about legal rights and responsibilities. An all-encompassing discussion of the many ways in which the law addresses questions of competence is beyond the scope of this article. For the sake of brevity, this section will focus on a few distinguishable points at which competence becomes an issue within the realms of healthcare and the criminal law, evaluate what substantive content various authors give to these terms, and assess how that content overlaps across areas of the law.

\section{A. Healthcare Decision-Making and Developmental Capacity}

In the realm of healthcare decision-making, specifically decisions about end-of-life care requiring an extremely high level of decisional capacity, the Hastings Center defines that capacity as existing when a patient has: "(a) the ability to comprehend information relevant to the decision, (b) the ability to deliberate [about choices] in accordance with [personal] values and goals, and (c) the ability to communicate [verbally or nonverbally] with caregivers." ${ }^{4}$ To meet this standard, a patient must be able to both reach a decision and commu-

(West 2001); S.D. Codified Laws $\S 32-12-6$ (Michie 2003). Other states issue unrestricted licenses to those sixteen or older, see, e.g., Mont. CodE ANN. §61-5-105 (2005); N.D. Cent. Code $\$ 39-06-03$ (1997), or those older than seventeen, see. e.g., Colo. Rev. Stat. $\S 42-2-105.5$ (2003); IDAHo CoDE $\S 49-303$ (Michie 2003). In a small number of states, a minor may consent to marriage, without parental permission, before the age of eighteen. See, e.g., OR. REv. STAT. $\$ 106.010$ (2003) (young person age seventeen or older may consent to marriage); GA. CODE ANN. $\$ 19-3-2$ (2004) (young person age sixteen or older may consent to marriage); Мıсн. CoMP. Laws $\$ 551.51$ (1998) (young person age sixteen or older may consent to marriage).

This article does not purport to speak to the difficulties of evaluating competence and decision-making capacity for pre-adolescent children-a task even more daunting than making this determination for adolescents. A basic premise of this article is that it is frequently a mistake to use the terms child or children to refer to all of those under the age of eighteen without reflecting on the significant developmental divide between those who have not yet reached adolescence and those who are closer to the end of their legal minority. By conflating these groups of minors, the law fails to appreciate the degree to which outcomes of competence evaluations will frequently be extremely different for adolescents versus young children.

${ }^{3}$ Rhonda Gay Hartman, Adolescent Autonomy: Clarifying an Ageless Conundrum, 51 HasTINGS L.J. 1265, 1266 (2000); see also Preston A. Britner, Suzanne J. LaFleur \& Amy J. Whitehead, Psychology and the Law: Evaluating Juveniles' Competence to Make Abortion Decisions: How Social Science Can Inform the Law, 5 U. ChI. L. Sch. Roundtable 35, 36 (1998) ("This disparity in standards for competence across legal domains underscores the political climate of contemporary legal policy and highlights the difficulty of defining 'competence' and applying such a definition, both within any one domain as well as across domains.").

4 The Hastings Ctr., Guidelines on Termination of Life-Sustaining Treatment and the Care of the Dying (1987); see also Jessica Wilen Berg et al., Constructing Competence: Formulating Standards of Legal Competence to Make Medical Decisions, 48 Rutgers L. Rev. 345, 351 (1996) (citations omitted). 
nicate that decision to the appropriate people. ${ }^{5}$ A patient who cannot meet these criteria is legally incompetent to make healthcare decisions.

A patient's ability to understand relevant information requires only that she grasp the concepts involved in an informed consent discussion. ${ }^{6}$ Thus, to meet the elements of the decision-making capacity inquiry, she must harbor an ability to appreciate the nature of the situation and its likely consequences by "apply[ing] information that is understood in a context-neutral sense to his or her own situation. ..."7 A patient with decision-making capacity will be able to manipulate information rationally, meaning that she will be able to weigh logically the risks and benefits of a proposed course of action. ${ }^{8}$

Though the law generally does not allow those under the age of eighteen to independently consent to healthcare, there are still circumstances in which it is necessary to evaluate the competence of minor patients. In such a case, just as is true for adults, an evaluator must determine the young person's "understanding of the proposed intervention, the risks, indications and alternatives, and the short-and long-term consequences of the decision." 9

The healthcare decision-making capacity of minors frequently emerges in discussions about abortion. For judges charged with determining a young woman's ability to make an abortion decision without including her parents, courts have looked beyond "social skills, level of intelligence, or verbal skills" 10 and focused on the minor's "experience, perspective, and judgment."11 The courts have not required that a young woman in a judicial bypass proceeding harbor adult level experience, that she be independent from her family, or close to the age of majority. ${ }^{12}$ Courts have defined maturity, and therefore competence in this context, with reference to

intellectual capacity, experience, and knowledge necessary to substantially understand the situation at hand and the consequences of the choices that can be made, or the capacity to understand and evaluate the type of procedure that the physician intends to use to perform the abortion and the possible complications associated with the use of the procedure and with the performance of the abortion itself. ${ }^{13}$

In the healthcare arena, a finding that a person is legally competent follows a determination that the subject is capable of giving informed consent to treatment, meaning consent that is knowing, intelligent and voluntary. ${ }^{14}$ This means that she has a decision-making capacity developed enough to allow her to understand her situation as it is explained to her, including the risks and

5 Berg et al., supra note 4 , at 352-54.

6 Id.

${ }^{7}$ Id. at 353-56 (citations omitted).

8 Id. at 357 .

9 Daniel A. Beals, Bioethics in Pediatric Practice, June 30, 2004, available at http://www. emedicine.com/ped/topic2769.htm.

10 William H. Danne, Jr., Annotation, Validity, Construction, and Application of Statutes Requiring Parental Notification of or Consent to Minor's Abortion, 77 A.L.R. 1, 2 (2005).

11 Id.

12 Id.

13 Id.

14 Britner et al., supra note 3, at 40 ("Competence' is a term that often subsumes the three conditions necessary for a legally valid medical treatment decision. An informed decision must be made voluntarily, knowingly, and intelligently."). 
benefits of proposed treatments or a failure to treat, and to decide how to proceed based upon her own desires and values. Finally, she must be able to communicate that decision to those charged with implementing or respecting her choice.

\section{B. Criminal Culpability and Developmental Capacity}

The elements of competence for purposes of criminal culpability are not wholly dissimilar from those discussed in the previous section on healthcare decision-making. When a young person stands accused of a crime, it is initially necessary to evaluate her competence to stand trial. Competence for this purpose is a combination of two factors: (1) her ability to assist counsel in her own defense, and (2) her decision-making competence. ${ }^{15}$

The recommendations that emerged from the 1995 conference on the Ethical Representation of Children incorporated specific language detailing how an attorney for a young person should go about determining the client's ability to participate in her own legal representation. According to the conference recommendations, lawyers for young people should assess the client's developmental stage by referring to cognitive ability, socialization, and emotional development. ${ }^{16}$ The lawyer should also evaluate the client's "expression of a relevant position," her "individual decision-making process," and her "ability to understand consequences."17

A young person's ability to act as a meaningful participant in her own defense and communicate with her attorney has been termed "adjudicative competence"18 or decisional competence. ${ }^{19}$ The core skills required for such competence are an ability to understand the criminal proceeding, make decisions about her defense, and provide assistance to her attorney. ${ }^{20}$ More specifically, a decisionally competent young person will have "the capacity to engage in reasoning processes and to make judgments with input from counsel."21 Her advanced decision-making capacity will allow her to evaluate consequences, consider options, and make decisions based on her personal calculations and preferences. $^{22}$

15 Thomas Grisso, The Competence of Adolescents as Trial Defendants, 3 Psychol. Puв. PoL'Y \& L. 3, 8 (1997) (citing Richard J. Bonnie, The Competence of Criminal Defendants: A Theoretical Reformulation, 10 BeHAv. Scr. \& L. 291 (1992)).

${ }^{16}$ Recommendations of the Conference on Ethical lssues in the Legal Representation of Children, 64 FordHAM L. Rev. 1301, 1313 (1996) reprinted in 6 NEv. L.J. 1408 (2006). 17 Id.

18 Barry C. Feld, Competence Culpability, and Punishment: Implications of Atkins for Executing and Sentencing Adolescents, 32 HofstRA L. Rev 463, 523 (Winter 2003) (citation omitted). An ability to assist counsel depends upon the existence of the "capacity to grasp the meaning of the legal procedure and to participate in it with counsel." Grisso, supra note 15 , at 8 . This means that the defendant must be able to "understand the proceeding . . and appreciate the significance of these matters for his or her own situation." Id. Finally, competence to assist counsel requires the ability to communicate information to counsel that is relevant for a defense." Id.

${ }^{19}$ Grisso, supra note 15 , at 8 .

20 Feld, supra note 18.

${ }^{21}$ Grisso, supra note 15 , at 8.

22 Id. 
To manifest this competence, the defendant "must understand the purpose of the trial process, to provide information to and process information from counsel, to reason appropriately, and realistically to apply that information to the legal situation she confronts." ${ }^{23}$ In the criminal court context, with its low threshold for establishing a defendant's competence for finding him criminally culpable, it is extremely important to discover the cases in which youthful incapacity should mitigate responsibility or punishment. ${ }^{24}$

While not always discussed in such terms, courts must also evaluate juvenile defendants on their competence to commit a crime, meaning their ability to intend to engage in the criminal activity. This inquiry again touches upon the criminal defendant's developmental capacity to understand the consequences of her actions and her choice to act in the face of those consequences.

In the end calculus, while there may be some differences in nuance, the question of competence or capacity, whether in reference to healthcare, criminal culpability, or participating in a lawyer/client relationship, focuses on a few narrow and overlapping categories. At its core, decision-making capacity is a central component of an individual's overall competence. The fundamental inquiry, whether termed an evaluation of competence or capacity, is whether the person being judged possesses the requisite skill to understand her circumstances when explained to her and make reasoned, even if not reasonable, choices about how to proceed. If so, she possesses the required competence and the law should treat her accordingly. If, however, she lacks these skills of understanding and reason, she is incompetent and the law, in whatever context, should treat her in accordance with that finding.

In criminal law, establishing a defendant's inadequate decision-making skills could lead to a determination that the defendant is not criminally culpable or is not morally culpable to an extent that justifies imposition of the death penalty or a life sentence. In the context of a lawyer client relationship, a lack of competence might require a lawyer to seek a guardian for a client, while still endeavoring to include the client in whatever level of decision-making is appropriate given her skill level. Finally, in the context healthcare, a lack of competence or capacity might translate into a determination that a young person is incapable of making independent decisions thereby requiring the intervention of an adult decision maker.

Given that judgments about competence or the lack thereof carry with them serious consequences in both criminal and healthcare care law, there is a tendency to seek easy ways to measure the presence or absence of such competence. Presumptions of competence may help to streamline some court proceedings, but these presumptions may lead to unintended or undesirable results.

A presumption of incompetence for purposes of healthcare decision-making that offered no exceptions to the usual requirement of parental involvement in all healthcare decisions made by young people may discourage some minors from accessing needed care for fear of having to confront their parents. This potential consequence is part of the rationale behind statutes that allow young people to access treatment for sexually transmitted infections, prenatal care,

${ }^{23}$ Feld, supra note 18 , at 523-24 (citation omitted).

24 Id. 
abortion, or drug treatment without parental consent or notification. ${ }^{25}$ A presumption of adolescent incompetence that made these healthcare emancipation statutes suspect could have a detrimental impact on young people.

On the positive side, in the criminal context, a presumption of adolescent incompetence would shield minors from criminal culpability, extended criminal sentences, incarceration in adult facilities, or the death penalty and could create greater opportunities for rehabilitation of youthful offenders.

If the law presumes that young people are decisionally capable in the healthcare context, it is more likely that minor patients can form trusting, confidential relationships with their healthcare providers thus potentially improving treatment outcomes. Further, there will be less incentive for young people to avoid needed medical care for fear of reprisals from their parents. On the negative side, if the legal system presumes that youthful offenders are decisionally capable, these young people will become eligible for severe adult sanctions, including the death penalty, and have fewer opportunities for education and rehabilitation. ${ }^{26}$

Ultimately, this article concludes that it is possible to understand the developmental richness of young people in a way that may protect an adolescent from adult prisons and criminal culpability while also acknowledging that young people, in most circumstances, can and should be allowed to engage in independent healthcare decision-making. Thus, to the extent that presumptions of competence or incompetence could serve a valid purpose in dealing with adolescents, it would be appropriate and consistent to presume incompetence in the criminal law and presume competence for purposes of healthcare decisionmaking. This split makes sense when one considers that the settings in which decision-making takes place about healthcare or criminal activity are radically different and, therefore, the quality and character of adolescent decision-making is wildly divergent in these two areas. I will elaborate on the question of context-specific decision-making in Part IV. First, I will turn to an explanation of just how differently advocates and the courts describe the decision-making capacities of young people in criminal and healthcare decision-making.

25 Jennifer Rosato, Let's Get Real: Quilting a Principled Approach to Adolescent Empowerment in Health Care Decision-Making, 51 DePaul L. Rev. 769, 778 (2002).

26 It is not a given that a default position of adult decision-making capacity would necessarily work to the detriment of adolescents facing criminal prosecution. As explained by one author:

Decisional capacity for adolescents who are 15 and older should be carefully considered in the juvenile justice] context. A chief consideration should include acknowledgement of adolescent decisional ability, which would not careen the rehabilitative course of the juvenile justice system; rather, it would comport with social norms embraced by this area of the law, along with trends in other legal arenas, such as family law and tort, that accord recognition to adolescent decisional ability. Forthright recognition of decisional capability, coupled with attention to constitutional safeguards and effective legal representation for adolescent defendants, would enhance fairness and uniformity, yet provide defense counsel the opportunity to proffer mitigating evidence, such as diminished capacity, when appropriate. Consequently, a decisional autonomy approach toward adolescents accused of criminal offenses would increase fact finding accuracy and fair treatment calibrated by essentials of due process, especially in a climate where adolescents are increasingly charged with crimes and confronted with criminal sanctions.

Hartman, supra note 3, at 1300-01 (citations omitted). 


\section{Defining the Problem: Are Adolescents Big Kids, Little AdULTS, OR NEITHER?}

This section describes how advocates and the Supreme Court have utilized developmental literature and arguments based on that literature to justify various courses of action in criminal law and healthcare decision-making law as they pertain to adolescents. While abortion and the death penalty are extreme subjects to use as the basis of this discussion, they are two of the more useful areas in which to confront the issue of adolescents and development for at least two reasons.

First, both subjects are so contentious and politically divisive that they generate copious amounts of scholarly discussion and multiple Supreme Court cases. Thus, there is a rich background of discussion illuminating the ways in which the law has configured adolescents. Further, the disparate way that advocates have positioned adolescents in the context of these discussions provides a great base for determining how to make sense of seemingly contradictory assertions.

Second, both abortion and the death penalty have a particular impact on adolescents as opposed to young children because it is those who are on the margins of legal majority for whom it is most difficult to dictate a consistent position on the question of competence. It is rare, though not impossible, for a six-year-old to possess adult competence. It is significantly more likely that one will find an advanced level of competence among the average, rather than the extraordinary, sixteen-year-old. This reality fosters difficulties in staking out a position on legal capacity for adolescents.

Thus, by focusing on the extremes of imposition of the death penalty and abortion decision-making, this Part identifies the dichotomous understanding of adolescents within the law.

\section{A. Evaluating the Adolescent Patient's Competence}

Juvenile justice advocates claim adolescent incapacity to engage in criminal behavior with culpability comparable to that of adults. Strategically, this position supports the goal of keeping young people out of the adult criminal justice system, including adult prisons, and avoiding the possible use of the death penalty for adolescents. By contrast, advocates seeking access to various forms of healthcare on behalf of young people regularly advocate a view of adolescent decision-making competence that is on par with that of adults. These advocates urge changes in the current healthcare decision-making legal canon that keeps young people from making independent decisions about their own healthcare in most circumstances. For these advocates, the law's vision of young people as underdeveloped and incompetent for purposes of most healthcare decisions is deeply flawed.

Those writing and working in the healthcare arena do not proffer a singular position on adolescent decision-making capacity. It is clear, though, that concerning certain healthcare related topics, there are many who believe that a broad based policy of adolescent incapacity is developmentally inaccurate and 
fails young people and their families. ${ }^{27}$ As patient's reach age thirteen to fifteen, healthcare providers should become increasingly concerned with evaluating the decision-making capacity of their young patients and seeking their assent, if not consent, to treatment. ${ }^{28}$ Research suggests that at some point during early-to mid adolescence, young people in various research settings exhibit decision-making capacities on par with those of adults. ${ }^{29}$ Based on this type of research, the range of voices calling for changes in the law spans from those focused on adolescent girls and the decision to terminate a pregnancy, ${ }^{30}$ to those who concentrate on adolescents and right to die issues, ${ }^{31}$ and others who make broad based claims about adolescent capacity to direct their own healthcare. ${ }^{32}$

In an earlier writing, this author expressed opposition to the law's general command that those under the age of eighteen not be able to make their own decisions about healthcare, instead granting wide authority and sole legal decision-making power to parents and other adult caretakers. ${ }^{33}$ Though there are

27 See, e.g., Michelle Oberman, Minor Rights and Wrongs, 24 J. L. MED. \& ETHICs 127 (Summer 1996); Rosato, supra note 25; A Proposal to Simplify the Law of Teenage Medical Decision-Making, 22 J. LEGAL MED. 501-32 (December 2001) (arguing for a bright line rule of allowing those sixteen and older to make routine healthcare decisions independent of parents or guardians).

${ }^{28}$ See, e.g., Beals, supra note 9 ("Between age 13 years and legal adulthood, pediatricians should evaluate the child's ability to understand and provide informed consent."). Seeking assent is conceptually similar to an informed consent process except that it seeks to have a young patient agree to a course of treatment even though she does not have the power to actually give or withhold legally binding consent. Am. Acad. of Pediatrics Comm. on Bioethics, Informed Consent, Parental Permission, and Assent in Pediatric Practice, 95 Pediatrics 314, 314 (1995) [hereinafter Pediatrics Comm.].

29 See, e.g., Lois A. Weithorn \& Susan B. Campbell, The Competency of Children and Adolescents to Make Informed Treatment Decisions, 53 CHILD Dev. 1589, 1595-96 (1982); David G. Scherer, The Capacities of Minors to Exercise Voluntariness in Medical Treatment Decisions, 15 Law \& Hum. Behav. 431, 436 (Aug. 1991); Thomas Grisso \& Linda Vierling, Minors' Consent to Treatment: A Developmental Perspective, 9 Prof. Psychol. 412 , 425 (Aug. 1978). One author summed up relevant research as follows:

Overall, the findings of informed consent researchers have been quite consistent. Minors, especially adolescents, are more similar to adults than the law assumes in both the choices they make and in the logical processes they follow. This is not to say that the results of all of these investigations have been entirely consistent; but by and large, minors aged 14 years and higher make decisions regarding the waiver or rights or consent to medical procedures in generally the same manner that adults do. In some situations, children as young as nine years choose outcomes congruent with those chosen by adults, but the processes and reasoning behind these decisions are different. Analyses of social costs, however, may emphasize the need to consider judgment factors (e.g., consideration of social consequences) as well as cognitive and reasoning ability in determining adolescents' legal capacities.

Britner et al., supra note 3, at 46 (citations omitted).

30 See, e.g., Britner et al., supra note 3; Heather Boonstra \& Elizabeth Nash, Minors and the Right to Consent to Healthcare, The Guttmacher Report on Pub. Pol'y, Aug. 2000, at 4.

31 Ann Eileen Driggs, The Mature Minor Doctrine: Do Adolescents Have the Right to Die?, 11 Health Matrix 687 (2001).

32 See, e.g., Walter J. Wadlington, Consent to Medical Care for Minors, in CHILD.'s CoMPETENCE TO ConsENT; Hartman, supra note 3, at 1269; Weithorn \& Campbell, supra note 29, at $1595-96$.

33 Kimberly M. Mutcherson, Whose Body Is It Anyway: An Updated Model of Healthcare Decisionmaking Rights for Adolescents, 14 Cornell J. L. \& PuB. Pol'y 251 (2005). 
critical exceptions to the general rule of adolescent capacity, ${ }^{34}$ I contend that such exceptions are too limited to achieve the goal of protecting and promoting adolescent autonomy ${ }^{35}$ and articulated a standard of shared decision-making power between parent and minor children age fourteen and older with an opportunity for adolescents to opt-out of sharing decision-making in some cases. The exception to the power of opt-out exists when the young person lacks decision-making capacity or if the young person is making a decision with a substantial risk of leading to death or permanent disability. ${ }^{36}$ A shared decision-making model based on a presumption of adolescent competence directly conflicts with the basic legal regime premised upon a belief that all minors, whether seven or seventeen, are incapable of mature decision-making.

The basis of the shift in the legal regime for which this author has argued is twofold. First, the argument rests on a belief that to deny adolescents the opportunity to be equal participants in decisions about their own healthcare and

34 The common law mature minor exception combats this baseline assumption of incompetence in situations where it is patently false or inappropriate. This exception holds that a person under the age of majority who evidences sufficient maturity, as assessed by a presiding judge, may make independent healthcare decisions. JAMES MORRISSEY ET AL., CONSENT and Confidentiality in the Health Care of Children and Adolescents 2 (1986). Courts have used this exception to allow young people who possess the requisite indicia of maturity to make serious and even life-ending medical decisions before they have reached the age of eighteen. See, e.g., In re E.G., 549 N.E.2d 322, 325 (Ill. 1989) (court allowed seventeen-year-old Jehovah's witness dying from leukemia to refuse life-saving blood transfusions); In re Swan, 569 A.2d 1202 (Md. 1990) (allowing parents to effectuate the desire of a seventeen-year-old in a persistent vegetative state to end artificial nutrition). While the baseline legal rule is one of adolescent incapacity, as Justice Kennedy indicates in his Roper v. Simmons opinion, in the context of healthcare, there are significant exceptions to a rule of broad based adolescent incapacity. While it is true that young people will generally need to secure parental permission to access healthcare, a majority of states allow a young person to make independent healthcare decisions about pregnancy or in relation to a known or suspected sexually transmitted infection. See, e.g., Ala. Code $\S 22-8-6$ (2004); CAL. Fam. Code $\$ 6925$ (West 2004); Haw. Rev. Stat. AnN. $\$ \$ 577 A-2,577$ A-3 (Michie 2002) (allowing for disclosure to parents at the discretion of the healthcare provider); IDAHO CODE \$ 39-4302 (Michie 2004). Some states also allow independent healthcare decisionmaking for young people who are married or who have joined the military. See, e.g., IND. CODE ANN. § 16-36-1-3(a) (Michie 2002) (providing that minor must be emancipated, married, divorced, in the military, authorized by statute, or fourteen or older and living away from parents); Kan. STAT. ANN. § 38-123b (2005) (requiring minor to be sixteen or older); Miss. CODE ANN. \$ 41-41-3 (1972) (providing that minor must have intelligence to understand procedure and its consequences); N.J. REV. STAT. § 9:17A-4 (2006) (providing that a healthcare provider may inform parents at its discretion). Similar status emancipation statutes for healthcare purposes allow young people living with sexually transmitted infections to access disease related healthcare independent of their parents. Cal. Health \& SafeTY Code $\S 121010$ (West 2006); ConN. Gen. STAt. \$39a-592 (1958) (requires parental consent unless healthcare provider believes that parental involvement would result in non-treatment or if minor request that parents not be informed); DEL. CoDE. ANN. tit. $16 \S 710$ (1974); D.C. CoDE ANN. $\$ 7-1605$ (1981) (allows for testing for HIV and healthcare provider may inform parents at her discretion); GA. CODE. ANN. \$ 31-17-7(a) (2004) (healthcare provider may disclose to parents at her discretion); HAw. Rev. STAT. AnN. $\$ \$ 577 \mathrm{~A}-2,577 \mathrm{~A}-3$ (Michie 2002) (healthcare provider may disclose at her discretion); N.H. Rev. Stat. ANN. $\S 141-\mathrm{C}: 18$.(II) (2002) (minor must be fourteen or older).

35 Mutcherson, supra note 33, at 277.

36 Id. at 304. 
provide opportunities for independent healthcare decision-making is to reject the innate autonomy of young people. ${ }^{37}$ Second, available developmental literature reliably supports a contention that most adolescents who have attained the age of fourteen possess the ability to make reasoned decisions about their own healthcare and should be supported in doing so. ${ }^{38}$ Failing to recognize this reality leads only to fracture in families and in healthcare provider/patient relationships. ${ }^{39}$

Eschewing a shared decision-making model, others have emphasized a desire to favor young people with more far-reaching powers of parental exclusion. Especially in the abortion arena, advocates have repeatedly made calls to change the law to unburden young women from any requirement to involve parents or judges in their decisions about ending a pregnancy. ${ }^{40}$ Others have sought to limit the power of judges in judicial bypass proceedings to counteract potential political or gender bias by, for instance, incorporating a presumption of maturity into these proceedings. ${ }^{41}$ Frequently, references to research standing for the proposition that young women are developmentally capable of making their own decisions about pregnancy ${ }^{42}$ accompany these calls for change.

In an amicus brief filed in conjunction with State of Ohio v. Akron Center for Reproductive Health, ${ }^{43}$ the American Psychological Association ("APA") argued against parental notification or consent requirements based in part on a belief that young women possess the decision-making capacity necessary to make informed decisions about abortion. The authors of the brief explained:

Psychological theory and research about cognitive, social and moral development strongly supports the conclusion that most adolescents are competent to make informed decisions about important life situations. . . . Developmental psychologists have built a rich body of research examining adolescents' capacities for understanding, reasoning, solving problems and making decisions, especially in comparison to the same capacities in adults.

Research consistently supports the conclusion that there is a predictable development during late childhood and early adolescence of the capacity to think rationally about increasingly complex problems and decisions. Although there are several competing theories of cognitive development, these theories each recognize that a revolution in rationality occurs during early adolescence. ${ }^{44}$

The APA specifically makes a claim that those who have reached the age of fourteen or fifteen reason about moral dilemmas in a similar way as adults and comprehend "social rules and laws." 45 Young people in this period of middle adolescence possess "adultlike intellectual and social capacities includ-

37 Id. at $272-77$.

38 Id. at 283-91.

39 Id. at 280-83 and 291-98.

40 See, e.g., Britner et al., supra note 3.

41 Suellyn Scarnecchia \& Julie Kunce Field, Judging Girls: Decision Making in Parental Consent to Abortion Cases, 3 Mich. J. Gender \& L. 75 (1995).

42 See, e.g., Nancy E. Adler, et al., Abortion Among Adolescents, 58 AM. Psychologist 211 (March 2003); Britner et al., supra note 3, at 40.

43497 U.S. 502 (1990).

44 Brief for American Psychological Association, et al. as Amici Curiae Supporting Petitioners/Cross-Respondents, Ohio v. Akron Ctr. for Reprod. Health, 497 U.S. 502 (1990) (Nos. 88-1125, 88-1309) [hereinafter APA Akron Brief].

45 Id. 
ing specific abilities outlined in the law as necessary for understanding treatment alternatives, considering risks and benefits, and giving legally competent consent." 46

It is the case, then, that a significant number of scholars and advocates believe that young people harbor reasoning and understanding capacities on par with those of adults several years before their eighteenth birthdays. Given that these young people possess such advanced abilities, it is wrong to assume that they are not competent to make many of their own healthcare decisions without the aid, input, or control of their parents.

\section{B. The Supreme Court and Adolescent Patients}

The Supreme Court has struggled to articulate a coherent position on adolescents and access to healthcare that protects young people from bad decisions while respecting their growing decision-making capacities. As is true with the death penalty in the context of criminal law, abortion cases force the Court to answer the question of the role of adolescents within families and the existence, or lack thereof, of adolescent ability to make significant decisions with far reaching consequences. ${ }^{47}$

In Bellotti v. Baird, in which the Court adjudicated the Constitutionality of a parental consent for abortion statute, the Justices faced a named plaintiff representing the "class of unmarried minors in Massachusetts who have adequate capacity to give a valid and informed consent [to abortion], and who do not wish to involve their parents." 48 That the courts allowed this young woman to proceed as a representative of young people with sufficient maturity and skills to make abortion decisions indicates some appreciation for the fact that there are minors who are capable of informed and mature decision-making.

In the course of declaring the challenged parental consent statute unconstitutional, the District Court in Bellotti noted that potentially a sizeable majority of seventeen-year-olds and a significant portion of those sixteen and younger are capable of giving informed consent to an abortion procedure. ${ }^{49}$

Whereas the lower court acknowledged the decision-making capacity of many pregnant women under the age of eighteen, the Supreme Court based its

\footnotetext{
46 Id; see also Michael A. Grodin \& Joel J. Alpert, Informed Consent and Pediatric Care, in Child.'s Competence to Consent 99 (Gary B. Melton et al. eds., 1983) ("For many consent decisions, the older child (13 years or above) is developmentally competent to make reasonable judgments as well as conceptualize and analyze actions and consequences. Within the framework of a particular psychosocial situation, it would appear quite sufficient to utilize sole consent by minors for the initiation and carrying out of a therapeutic regimen.").

47 Bellotti v. Baird, 443 U.S. 622, 639 (1979) ("Massachusetts has attempted to reconcile the constitutional right of a woman, in consultation with her physician, to choose to terminate her pregnancy as established by Roe v. Wade, 410 U.S. 113 (1973), and Doe v. Bolton, 410 U.S. 179 (1973), with the special interest of the State in encouraging an unmarried pregnant minor to seek the advice of her parents in making the important decision whether or not to bear a child").

$48 \mathrm{Id}$. at 626.

49 Id. at 631 ("many, perhaps a large majority, of 17-year olds are capable of informed consent, as are a not insubstantial number of 16-year olds, and some even younger." Id. citing Baird v. Bellotti, 450 F. Supp. 997, 1001 (Mass. 1978) (Baird III)).
} 
analysis on its earlier jurisprudence allowing states to circumscribe the choices of young people where "serious consequences" might result. ${ }^{50}$ The court based these rulings on its recognition that "during the formative years of childhood and adolescence, minors often lack the experience, perspective, and judgment to recognize and avoid choices that could be detrimental to them. ${ }^{51}$

In language mirroring later pronouncements in cases involving juvenile defendants, the Court explains that their immaturity prevents minors from making "fully informed choices that take account of both immediate and long-range consequences." 52 As such, according to the Court, it is appropriate and constitutional to legislate in a manner that encourages, if not mandates, parental involvement in the abortion decisions of unmarried minors.

Particularly in the context of abortion, pro-choice advocates have long forcefully made the argument for adolescent capability to make independent abortion related decisions. ${ }^{53}$ There is a significant body of literature that stands for the proposition that young women are, in fact, largely capable of making decisions about terminating a pregnancy without the assistance of their parents. $^{54}$ The APA has asserted that available studies support the claim that young women between fourteen and eighteen-years-old are no different from adults when it comes to the factors related to legal competence and abortion decision-making. ${ }^{55}$

Supreme Court jurisprudence, however, undermines the position of prochoice advocates. Thus far, the Court has refused to uphold state parental consent statutes that provide parents with a unilateral veto of a young woman's choice to terminate a pregnancy. ${ }^{56}$ Though states cannot confer veto power on parents, the Court does allow states to strongly encourage parental involvement

so Id. at 635.
s1 Id.
s2 Id. at 640.

53 See, e.g., SOC'y FOR AdOLESCENT MED., Position Paper: Reproductive Healthcare for Adolescents, 12 J. Adolescent Health 649 (1991) ("[T]he decision to terminate a pregnancy should rest with the pregnant adolescent in concert with the advice and counsel of her physician."); Brief of the American College of Obstetricians and Gynecologists as Amici Curiae Supporting Appellees at 88-805 and Cross Respondents at 88-1309, Ohio v. Akron Ctr. for Reprod. Health, 497 U.S. 502 (1990).

54 According to the APA:

The two most directly relevant studies compared abortion decisionmaking by adolescents and adults at the time they received pregnancy tests in actual treatment settings. Results of both are consistent with the research and theory reviewed above showing that "adolescents are as able to conceptualize and reason about treatment alternatives as adults are."

APA Akron Brief, supra note 44 (citing Lewis, A Comparison of Minors' and Adults' Pregnancy Decisions, 50 Aм. J. Orthopsychiatry 446 (1980); Ambuel, Developmental Change in Adolescents' Psychological and Legal Competence to Consent to Abortion: An Empirical Study and Quantitative Model of Social Policy (1989) (Dissertation Abstracts Int'l)).

55 APA Akron Brief, supra note 44 ("[E]mpirical studies of treatment and abortion decisionmaking have found no differences between adolescents aged 14-18 and adults in factors related to legal competence. There is therefore no scientific foundation for the States' assumption that adolescents' decisions to have an abortion are generally less thoughtful and informed than adults' decisions.").

56 Bellotti v: Baird, 443 U.S. 622 (1979); Planned Parenthood of Cent. Missouri v. Danforth, 428 U.S. 52, 74-75 (1976); City of Akron v. Akron Ctr. for Reprod. Health, Inc., 462 U.S. 416, 439-41 (1983). 
through laws requiring parental notification of a young woman's decision to end a pregnancy. ${ }^{57}$ By taking this position, the Court does not articulate a belief in widespread adolescent competence. To the contrary, Supreme Court abortion jurisprudence makes clear that the Court generally trusts parents more than young women to make the best decisions about continuing or ending a pregnancy.

\section{As the Court explained in Bellotti:}

As immature minors often lack the ability to make fully informed choices that take account of both immediate and long-range consequences, a State reasonably may determine that parental consultation often is desirable and in the best interest of the minor. It may further determine, as a general proposition, that such consultation is particularly desirable with respect to the abortion decision—one that for some people raises profound moral and religious concerns. ${ }^{58}$

When a young woman determines that consultation with her parents prior to consenting to an abortion is not in her own best interest, the Court allows states to establish a judicial bypass system that substitutes judges for parents in the minor's decision-making process. Therefore, abortion jurisprudence ultimately cannot stand for the proposition that young women are developmentally capable of making decisions to terminate a pregnancy without consultation with parents or the judicial system. Instead, the Court's abortion decisions reinforce a paradigm of adolescent incompetence. ${ }^{59}$

Though the abortion debate is probably the most politically fraught arena in which the Supreme Court struggles with minors and healthcare decisionmaking, it is just one context in which the Court has limited adolescent healthcare decision-making. In Parham v. J.R., the Supreme Court faced the vexing question of what process is due to a minor child when parents seek to have that child committed to a state operated mental health facility. ${ }^{60}$ There was no dispute in the case over the fact that children have a liberty interest in avoiding unnecessary confinement and medical treatment. ${ }^{61}$ In describing the relationship among parents, minor children, and the State, the Court wrote:

Our jurisprudence historically has reflected Western civilization concepts of the family as a unit with broad parental authority over minor children... . The law's concept of the family rests on a presumption that parents possess what a child lacks in maturity, experience, and capacity for judgment required for making life's difficult decisions. More important, historically it has recognized that natural bonds of affection lead parents to act in the best interests of their children. ${ }^{62}$

57 Planned Parenthood v. Casey, 510 U.S. 1309 (1994).

58 Bellotti, 443 U.S. at 640.

59 As explained by one author:

Thus, under the model constructed in Bellotti II, pregnant girls seeking abortions, though very likely to receive judicial consent, have not been granted autonomy as the term is normally understood. Rather, they have been granted a peculiar sort of burdened autonomy that substitutes state authority for parental authority, and that asks pregnant girls to show far more initiative and competence than the Court has asked of adult women seeking abortions.

Janet L. Dolgin, The Fate of Childhood: Legal Models of Children and the Parent-Child Relationship, 61 ALB. L. Rev. 345, 413-14 (1997) (citations omitted).

60 Parham v. J.R., 442 U.S. 584, 587 (1979).

61 Id. at 600.

62 Id. at 602 (citations omitted). In a similar vein, Justice Stevens writing separately to concur notes: 
In Parham, the Court acknowledged its earlier determination in abortion jurisprudence that parental power over minor children is not so extensive so as to let stand a state law creating an absolute parental veto over a minor woman's decision to end a pregnancy. ${ }^{63}$ However, the Court's characterization of adolescents remained firmly rooted in a belief of adolescent decision-making incapacity. The Court explained, "[m]ost children, even in adolescence, simply are not able to make sound judgments concerning many decisions, including their need for medical care or treatment." 64 Thus, the Court's jurisprudence on abortion and adolescents provides a foundation for other cases involving young people and healthcare decisions.

In its healthcare-decision making jurisprudence, the Supreme Court has trod a path of primarily protecting parental interest in directing the lives of their offspring and attempting to reconcile this interest with whatever Constitutional rights can be said to belong to minors. In the realm of abortion, while the Court acknowledges the significance of the abortion right that is at stake, the Court ultimately limits the right because of worry about a young woman's ability to responsibly exercise this right without adult intervention.

\section{Evaluating the Adolescent Criminal Defendant's Competence}

As previously described, there are at least two aspects of juvenile competence in the context of criminal prosecutions. The first encompasses a young person's ability to understand and control her actions before she engages in criminal behavior coupled with her ability to intend her bad acts and comprehend the consequences of her criminal conduct. The second is the adolescent criminal defendant's ability to understand the workings of the criminal justice system that will adjudicate her behavior, including the challenges and responsibilities of being in an attorney/client relationship. This second component of competence demands an evaluation of the adolescent criminal defendant's responsibility for her own defense as measured by her capability to appreciate the nature of criminal proceedings, waive her Miranda rights, and/or direct the actions of her defense counsel. ${ }^{65}$

Juvenile justice advocates have taken positions on both the question of decision-making capacity sufficient to justify criminal responsibility and the decision-making capacity sufficient to allow a young client to direct her legal representation. These advocates have fought for an understanding of adolescents as uniquely positioned; thus, calling into question the wisdom of adjudicating their alleged criminal acts in the adult criminal justice system. ${ }^{66}$

Under our law, parents constantly make decisions for their minor children that deprive the children of liberty, and sometimes even of life itself. Yet surely the Fourteenth Amendment is not invoked when an informed parent decides upon major surgery for his child, even in a state hospital. I can perceive no basic constitutional differences between commitment to a mental hospital and other parental decisions that result in a child's loss of liberty.

Id. at 624 .

63 Id. at 603.

64 Id.

65 Grisso, supra note 15; Thomas Grisso, Juveniles' Capacities to Waive Miranda Rights: An Empirical Analysis, 68 CALIF. L. Rev. 1134 (1980).

66 See, e.g., C. Antoinette Clarke, The Baby and the Bathwater: Adolescent Offending and Punitive Juvenile Justice Reform, 53 KaN. L. Rev. 659 (2005). 
Simultaneously, advocates have argued that young people can and should have access to the panoply of rights, including the right to counsel, routinely made available to adult defendants. ${ }^{67}$ Advocates have also argued that the lawyer's duty to an adolescent client in a criminal or delinquency proceeding is concomitant to that owed to an adult client in similar circumstances, including a duty to maintain confidences. ${ }^{68}$

\section{Competence and Criminal Culpability}

As to the first competence issue, that of the presence of sufficient competence to support a finding of criminal culpability, the law excuses a defendant from criminal responsibility only when he lacks the capacity or the fair opportunity to refrain from criminal conduct. ${ }^{69}$ Punishment for a crime should be proportional to the actor's blameworthiness and cannot solely be measured by the harm caused by the criminal act. ${ }^{70}$ When an accused lacks decision-making capacity entirely or has diminished capacity to make the wholly autonomous choices assumed by the criminal law, that defendant is "not as blameworthy as other offenders."71 Where there is diminished capacity, a finding of culpability may be altogether inappropriate or that diminished capacity may warrant a less severe punishment for the convicted defendant. ${ }^{72}$ Youth is frequently a marker of a diminished capacity that makes a defendant's action less blameworthy than might otherwise be the case.

67 Historian Steven Mintz writes:

Children's rights reformers stressed that juveniles were denied basic due process rights, even after the high court's decision in Gault. While Gault gave minors the right to written notice of charges, the right to cross-examine witnesses, the privilege against self-incrimination, and the right to cross-examine witnesses, it denied them other rights, such as indictment by a grand jury, release on bail, and a right to a public trial and a trial before a jury.

HuCK's RaFT 330-31 (2004).

68 Jean Koh Peters, The Roles and Content of Best Interests in Client-Directed Lawyering for Children in Child Protective Proceedings, 64 Fordham L. Rev. 1505, 1564 (1995); Recommendations of the Conference on Ethical Issues in the Legal Representation of Children, supra note 16 , at 1301 .

69 Joshua Dressler, Understanding Criminal LAw $§ 17.03[E]$ (3d ed. 2001) (discussing the personhood theory which requires that we "excuse people whose ability to reason practically is grossly disturbed or underdeveloped (e.g., insane people and infants) ... [and] those whose opportunity to reason practically is seriously undermined on an individual occasion (e.g., due to passion or coercion)"; Paul H. Robinson, Structure ANd Function IN CRIMINAL LAW 83 (1997) ("the actor can point to abnormal circumstances or abnormal characteristics that make it too difficult for the actor to appreciate the criminality or wrongfulness of his or her conduct or too difficult to conform his or her conduct to the requirements of law"). ${ }^{70}$ Laurence Steinberg \& Elizabeth S. Scott, Less Guilty by Reason of Adolescence: Developmental Immaturity, Diminished Responsibility, and the Juvenile Death Penalty, 58 AM. Psychologist 1009 (2003).

71 Feld, supra note 18, at 465; see also David O. Brink, Immaturity, Normative Competence, and Juvenile Transfer: How (Not) to Punish Minors for Major Crimes, 82 Tex. L. Rev. 1555,1572 (2004) ("If normative competence is a condition of responsibility, then the reduced or diminished normative competence of juveniles calls into question most of the punitive reforms to juvenile justice.").

72 Brink, supra note 71, at 1572-73 ("Insofar as punishment should be proportional to desert and desert is itself the product of the wrongfulness or harm of an agent's act and the agent's responsibility for the act, the diminished competence of juveniles provides a retributive rationale for reduced punishment for juveniles."). 
This societal understanding of the unique positioning of youthful offenders is part of the rationale for a system of juvenile justice separate from the system responsible for adult criminals. The evolution of the juvenile justice system over the years has sometimes been in tandem with the developmental literature. At other times, changes to the system came about in opposition to progress in scientific understanding of the cognitive development of children and adolescents. Two leading experts on adolescent development and capacity, Elizabeth Scott and Thomas Grisso, describe the periods of change as follows:

One way to think about the evolution of legal policies responding to youthful crime is in terms of the empirical account of adolescence that these policies tacitly express. From this perspective, the traditional (pre-Gault) juvenile court was shaped in important ways by a conception of errant youth as childlike, psychologically troubled and malleable. On this view, the job of the court was not to punish, but to rehabilitate and protect its charges. With the reform movement of the $1970 \mathrm{~s}$ and $1980 \mathrm{~s}$, a less idealized view of adolescence emerged, together with a growing skepticism about the potential for rehabilitation. Immature youth were seen as less culpable than adults, but not as blameless as children. Lacking experience and judgment, young offenders needed lessons in accountability. A perusal of the current landscape of juvenile justice reform suggests a view of delinquent youth as appropriately subject to adult punishment and procedures and thus as indistinguishable in any important way from their adult counterparts. ${ }^{73}$

The Grisso and Scott article concisely encapsulates several arguments made by juvenile justice advocates eager to protect young people from adult courts and adult sentences. The authors pose two central challenges to the idea of adolescents as indistinguishable from adult criminals that regularly appears in the scholarly literature. First, the authors refute the competence assumption that is blind to meaningful differences between adolescent and adult criminal actors. ${ }^{74}$ They explain:

Modern developmental psychology provides substantial, if indirect, evidence that adolescent choices about involvement in crime and their decisions as defendants in the legal process reflect cognitive and psychosocial immaturity. This evidence challenges contemporary juvenile justice policies which discount the importance of conventional notions of criminal responsibility and constitutional requirements for fair proceedings (neither of which the critics challenge directly) ${ }^{75}$

The second critique offered by Grisso and Scott is of the "utilitarian assumption" holding that the social cost of juvenile crime warrants adult sanctions for young offenders even if there are substantial developmental differences between adolescents and adults. ${ }^{76}$ This assumption proves untenable because most juvenile crime reflects transitory delinquency on the part of young people that will dissipate as they mature. ${ }^{77}$

73 Elizabeth S. Scott \& Thomas Grisso, The Evolution of Adolescence: A Developmental Perspective on Juvenile Justice Reform, 88 J. CRIM. L. \& CRIMINology 137, 138 (1998) (citations omitted).

74 Id. at 139; see also Steinberg, supra note 70 ("First, and most obviously, adolescents' level of cognitive and psychosocial development are likely to shape their choices, including their criminal choices, in ways that distinguish them from adults and that may undermines competent decision making.").

75 Scott \& Grisso, supra note 73 , at 139.

76 Id.

77 Id. 
As for decision-making capacity, which is a reflection of a young person's overall level of competence, Scott and Grisso explain that the capacity to make decisions grows throughout childhood and that while "there is great variability among individuals, preadolescents and younger teens differ substantially from adults in their abilities."78 As we age, our ability to process information and think in hypotheticals expands and we become more adept at using thinking skills acquired earlier in life. ${ }^{79}$

Ultimately, Scott and Grisso determine that when understood within the parameters of the excuse doctrine in criminal law, young people who are still in the throes of their development should benefit from a presumption of "diminished responsibility . . but not a lack of responsibility." sensible and defensible position that within the criminal justice system "[A]dolescence can usefully be conceptualized as a probationary period, in which young decision-makers learn to make responsible choices, without bearing the full costs of their mistakes." 81 If adolescence is seen in this way, then the legal system should provide consequences for young people who commit crimes so that it is understood that bad behavior warrants punishment but that punishment should be less severe than that meted out to older offenders "who have been given the opportunity to learn to make better choices." 82

Other scholars similarly argue against adult sanctions for adolescent criminal defendants, including asserting the inappropriateness of subjecting youthful offenders to life sentences without parole. ${ }^{83}$ As one advocate explained:

Criminal responsibility and moral blameworthiness hinge on cognitive and volitional competence. In a framework of deserved punishment, it is unjust to impose the same penalty on offenders who do not possess comparable culpability. Younger offenders are not as blameworthy as adults because they have not yet fully internalized moral norms, developed sufficient empathic identification with others, acquired adequate moral comprehension, or had sufficient opportunity to learn to control their actions. In short, they possess neither the rationality-cognitive capacity-nor the self-con-

78 Id. at 157.

79 Id. at $157-58$

80 Id. at 172; see also Feld, supra note 18, at 507 ("Youths differ from adults in their breadth of experience, short-term versus long-term time perspective, attitude toward risk, impulsivity, and the importance they attach to peer influence. These differences are linked to developmental process and affect their qualities of judgment and ability to appreciate the consequences of their actions. These generic developmental differences justify a less punitive stance toward younger offenders, which allows them to survive the mistakes of adolescence.") (citations omitted).

81 Scott \& Grisso, supra note 73 , at 175.

82 Id. (citations omitted); see also Feld, supra note 18, at 506-07 ("While adolescents possess sufficient cognitive competency to justify some degree of punishment, psycho-social maturity of judgment and temperance provide a broader framework through which to assess their culpability. Most youths lack the maturity of judgment characteristic of adulthood in a variety of areas - perceptions of risk, appreciation of future consequences, capacity for selfmanagement, and ability to make autonomous choices. Their decision-making preferences and values are in a state of transition, and they are prone to make poorer judgments than they would make several years later.") (citations omitted).

83 Feld, supra note 18, at 535; see also Amnesty International \& Human Rights W 2005), available at http://web.amnesty.org/library/pdf/AMR511622005ENGLISH/\$File/ AMR5116205.pdf. 
trol-volitional capacity - to justify equating their criminal responsibility with that of adults. ${ }^{84}$

Thus, according to these advocates for youth, juveniles should not be tried in adult courts or subjected to adult punishments because most adolescents lack the maturity and cognitive capacity required to evidence an adult level of culpability warranting severe criminal sanction. ${ }^{85}$

Advocates also argue that age should be a factor in criminal law because immaturity influences the possible deterrence effect of punishment. ${ }^{86}$ Young people who are inordinately affected by peer pressure, prone to recklessness and risky behavior, and inadequately equipped to consider consequences will not be likely to consider negative outcomes before engaging in criminal behavior, thus negating the use of criminal sanctions as a deterrent. ${ }^{87}$

\section{E. Adolescents as Clients}

The second aspect of competence in the juvenile justice arena is the adolescent defendant's ability to participate in and direct her own legal representation. ${ }^{88}$ In this context, Scott and Grisso explain:

Studies on youths' understanding of matters related to trials, such as the roles of participants and the trial process, have found that youths under the age of fourteen typically are deficient in their knowledge of the legal process and its basic purposes. In contrast, few differences in basic understanding of trial-related matters have been observed between adolescents fourteen to seventeen years of age and adults, when the populations studied were "average" adolescents. Similarly, a conventional grasp of the nature of legal rights typically has developed by mid-adolescence. Moreover, fundamental abilities of sensation, perception, and memory ordinarily have matured by early adolescence, suggesting that adolescents on average should be as capable as adults of providing accurate information to their attorneys from their experience. ${ }^{89}$

Other advocates offer a similar view on the ability of young people to meaningfully participate in and direct their own defense in juvenile delinquency proceedings. At the 1995 Fordham Conference, Ethical Issues in the Legal Representation of Children, the working Group on the Allocation of Decision Making took the position that "[t]he law should be changed to include the presumption that all children in delinquency cases are unimpaired and are therefore entitled to direct the attorney in the representation to the same extent as an adult client."90 This position goes further than simply asserting adolescent competence. The Working Group members aver a far-reaching claim of

84 Feld, supra note 18 , at 502.

85 Scott \& Grisso, supra note 73.

86 Brink, supra note 71 , at 1573 ("[T] potential criminals being rational calculators of expected utility. Immaturity compromises this assumption.").

87 Id.

88 This discussion carries over into any lawyer/client relationship involving a person under the age of eighteen. In all such situations, the lawyer struggles with questions of how the client's age and cognitive capacity should impact the representation.

89 Scott \& Grisso, supra note 73, at 169 (citations omitted).

90 Proceedings of the Conference on Ethical Issues in the Legal Representation of Children: Report of the Working Group on the Allocation of Decision Making, 64 FORDHAM L. REv. 1325, 1328 (1996). 
minor competence that includes even young children until and unless the child client proves to be incompetent. ${ }^{91}$ These advocates, then, stake out a strong position of adolescent competence to participate in and direct their own representation even in serious cases. The overall Conference Recommendations suggest, " $[t]$ he lawyer for a child who is not impaired (i.e., who has capacity to direct the representation) must allow the child to set the goals of the representation as would an adult client." 92

Focusing on child welfare proceedings, Professor Jean Koh Peters also urges lawyers for children to work within the paradigm of a "competence default" described as follows:

A child's lawyer should begin each representation with the presumption that the client can understand the legal issues in the case and express subjective perspectives or offer critical information about them. To the extent that the child's developmental state creates obstacles to communication and understanding, it is part of the lawyer's job to overcome them creatively in order to provide the child client with the benefits of an advocate who listens, informs, counsels, and answers questions.

Because this presumption is critical to effective representation, it can only be overcome when the lawyer has independent evidence, arising outside the representation, that the child is incapable of understanding the legal issue or expressing a view of it. $^{93}$

Though Peters focuses her writing on children in abuse and neglect proceedings, one could certainly extrapolate her position to adolescents facing criminal charges. These young people, who are entitled to legal representation, ${ }^{94}$ are also entitled to a lawyer who does not assume the young person's incompetence and who begins the representation with the belief that, as is true of an adult client, the client will make decisions about how the representation proceeds. Even in the face of a client who proves to be incompetent, Peters holds that "effective representation requires that the lawyer continue communicating with the client at the level of sophistication of which the client is capable .... [T] he determination that a child cannot 'adequately act in his own interest' must be made on a decision-by-decision, not on a child-by-child basis." 95

Some advocates admit that most average adolescents age fourteen and older are largely capable of understanding the mechanics of a criminal trial and the nature of their legal rights as criminal defendants. Youthful offenders, however, may suffer from deficiencies that impair their ability to participate in their own defense. ${ }^{96}$ Thus, while the law should protect young people from the extreme sanctions of a criminal justice system created for adults, these advocates also claim that the lawyer for a young person is obligated to respect the client's control of the representation as she would for an adult client unless the young person lacks competence. ${ }^{97}$

91 Id.

92 Recommendations of the Conference on Ethical Issues in the Legal Representation of Children, supra note 16, at 1301.

93 Peters, supra note 68, at 1564.

94 In Re Gault, 387 U.S. 1, 34-42 (1967).

95 Peters, supra note 68, at 1565.

96 See Scott \& Grisso, supra note 73, at 169 (citations omitted).

97 Report of the Working Group on the Allocation of Decision Making, supra note 90, at 1329-30. 
Some might argue that Scott, Grisso and others who place themselves in the same camp seek to have it all. They do this by citing adolescent deficiencies for purposes of avoiding adult sanctions and simultaneously asserting adolescent decision-making capacity for purposes of demanding the full rights of criminal defendants for young people. To plausibly make such claims, it is necessary to believe that one young person can be competent to engage in some activities and make some decisions, while still lacking adult competence in other areas. Part IV of this article explores this dichotomy in greater depth.

\section{F. The Supreme Court and Adolescent Defendants}

There are several competency evaluations that might take place over the course of a criminal proceeding. There might be a question of a defendant's competence to stand trial, ${ }^{98}$ or his competence, in terms of his ability, to form the requisite criminal state of mind. There may also be a question of whether, even if competent to stand trial and to be found guilty of a crime, the defendant's competence level is sufficient to find moral culpability to justify a given punishment, specifically the death penalty. ${ }^{99}$ This section will focus on the question of the competence of a juvenile defendant as a measure of the applicability of severe punishments.

Undeniably, the death penalty is an extreme punishment. One has no need to question why juvenile justice advocates work diligently and tirelessly to remove the death penalty from the realm of possible sanctions for crimes committed by minors. As evidenced by numerous articles in scholarly journals, many commentators believe that convicted criminals who commit capital crimes before they turn eighteen lack the developmental capacity to justify holding them fully culpable for those crimes, at least to the extent that to be held fully responsible would encompass the possibility of capital punishment. ${ }^{100}$

The campaign to protect young people from excessively harsh treatment in the criminal justice system has dealt with issues beyond imposition of the death penalty. Nevertheless, the continuing debate over capital punishment and the Supreme Court's recent curtailment of the use of capital punishment for juvenile offenders provides a ripe landscape for comprehending how commentators, courts, and advocates understand adolescent development for purposes of criminal justice proceedings. Further, because death is a uniquely harsh and finite punishment, it is in the context of the death penalty that the Court has "most thoroughly explored culpability, proportionality, and deserved punishment." 101

98 In general, a defendant is not competent to stand trial unless he possesses "sufficient present ability to consult with his lawyer with a reasonable degree of rational understanding-and whether he has a rational as well as factual understanding of the proceedings against him." Dusky v. United States, 362 U.S. 402, 402 (1960); see also Cooper v. Oklahoma, 517 U.S. 348 (1996).

99 Atkins v. Virginia, 536 U.S. 304, 306 (2002) ("Those mentally retarded persons who meet the law's requirements for criminal responsibility should be tried and punished when they commit crimes. Because of their disabilities in areas of reasoning, judgment, and control of their impulses; however, they do not act with the level of moral culpability that characterizes the most serious adult criminal conduct.").

100 See, e.g., Clarke, supra note 66; Feld, supra note 18.

101 Feld, supra note 18, at 466 (citations omitted). 
In many respects, Supreme Court jurisprudence in the area of juvenile justice has embraced Scott and Grisso's view of adolescent competence for purposes of conferring rights on juvenile defendants and adolescent incapacity for purposes of doling out criminal culpability and adult punishments. In 1967, the Court held that minors subjected to juvenile delinquency proceedings have a panoply of due process rights including the right to written notice of proceedings, the right to counsel, the right to refuse to self-incriminate, and the right to confront witnesses. ${ }^{102}$ However, in 1989, the Court held that states did not offend the Constitution by allowing the use of capital punishment when a defendant was sixteen or seventeen-years-old when he committed the crime for which he was punished. ${ }^{103}$

Most recently, the Court in Roper v. Simmons held that death sentences are unconstitutional when applied to young people convicted of capital crimes committed before they reach the age of eighteen. ${ }^{104}$ The Court's discussion of why it chose to depart from its earlier holdings that allowed the use of the death penalty for those sixteen and older at the time that they committed capital crimes illustrates the complexity of contending with adolescent defendants.

The road to a determination of the unconstitutionality of the juvenile death penalty began in cases decided long before the Court heard Roper. In Gregg v. Georgia, the Supreme Court observed that capital punishment serves the two social purposes of retribution and deterrence. ${ }^{105}$ The Court has continued to refer back to these two purposes in subsequent death penalty cases and when those social purposes are not served, the Court has found the use of the death penalty unconstitutional.

One arena in which the Court held that retribution and deterrence rationales failed was in the use of the death penalty against mentally retarded defendants. Using language that it would later recycle in cases involving juveniles and the death penalty, the Court wrote in Atkins v. Virginia: ${ }^{106}$

With respect to retribution ... the severity of the appropriate punishment necessarily depends on the culpability of the offender. . . If the culpability of the average murderer is insufficient to justify the most extreme sanction available to the State, the lesser culpability of the mentally retarded offender surely does not merit that form of retribution.

With respect to deterrence ... "it seems likely that "capital punishment can serve as a deterrent only when murder is the result of premeditation and deliberation." Exempting the mentally retarded from that punishment will not affect the "cold calculus that precedes the decision" of other potential murderers. Indeed, that sort of calculus is at the opposite end of the spectrum from behavior of mentally retarded offenders. The theory of deterrence in capital sentencing is predicated upon the notion that the increased severity of the punishment will inhibit criminal actors from carrying out murderous conduct. Yet it is the same cognitive and behavioral impairments that make these defendants less morally culpable-for example, the diminished ability to understand and process information, to learn from experience, to

102 In Re Gault, 387 U.S. at 1.

103 Stanford v. Kentucky, 492 U.S. 361 (1989); see also Eddings v. Oklahoma, 455 U.S. 1094 (1982).

104543 U.S. 551 (2005).

105428 U.S. 153,183 (1976).

106 Atkins v. Virginia, 536 U.S. 304, 319 (2002). 
engage in logical reasoning, or to control impulses-that also make it less likely that they can process the information of the possibility of execution as a penalty and, as a result, control their conduct based upon that information. . . ."107

Of further concern to the Atkins Court was the risk of the unjust application of the death penalty to developmentally disabled people who were more prone to make false confessions and who were less capable of putting on mitigating evidence. ${ }^{108}$ The Court also expressed concern that these defendants "may be less able to give meaningful assistance to their counsel and are typically poor witnesses, and their demeanor may create an unwarranted impression of lack of remorse for their crimes." 109 In the end, these factors all increased the risk that the developmentally disabled capital defendant might be wrongfully sentenced to death. ${ }^{10}$

One cannot dispute the importance of Atkins to the Court's repudiation of the juvenile death penalty in Roper. The Roper majority, many of the Roper amici writing for Respondent Roper, and other scholars rely heavily on comparisons between adolescents and the developmentally disabled to justify a ban on the use of capital punishment for minors. ${ }^{111}$ In both cases, while a defendant, either developmentally disabled or a minor, may have a level of decisionmaking capacity that allows a jury to find sufficient criminal culpability to support a conviction, it does not follow that these defendants act with the moral culpability necessary to warrant imposition of the death penalty. ${ }^{112}$

In Roper, the Court and several amici used comparisons between adolescents and the developmentally disabled to explain why adolescents were generally incapable of evidencing a level of moral culpability sufficient to support both criminal responsibility and use of the ultimate punishment of death. ${ }^{113}$ As the American Bar Association ("ABA") explained in its amicus brief:

Juveniles share nearly all of the developmental characteristics of the mentally retarded that support their categorical ineligibility for the death penalty. Like the mentally retarded, juveniles have decreased abilities to regulate their actions, understand the correlation between their actions and the consequences of those actions, and to appreciate the impact of the resulting punishment for their actions. Moreover, recent scientific research supports the conclusion that the brains of juveniles are less developed than those of non-mentally retarded adults. Moreover, juveniles have fewer life experiences to inform their decision making. Thus, like the mentally retarded, while juveniles may know the difference between right and wrong and may be competent to stand trial, they are less competent decision makers than non-men-

\footnotetext{
107 Id. at 319-20 (citations omitted).

108 Id. at 320-21 (citation omitted).

109 Id. at 321.

110 Id. at 320-21 (citation omitted).

111 See, e.g., Feld, supra note 18, at 477-78 ("Characteristics that reduce the culpability of mentally retarded offenders-susceptibility to peer influences, a propensity to act impulsively without thinking about consequences, and immaturity of judgment-have relevance to the criminal responsibility of adolescents.").

112 Atkins v. Virginia, 536 U.S. 304 (2002).

113 Roper v. Simmons, 543 U.S. 551 (2005).
} 
tally retarded adults because they have underdeveloped decision making capacities. $^{114}$

Amici also argue that, as is true for the developmentally disabled, imposing the death penalty on juveniles does not serve the retribution and deterrence rationales. Retribution fails because it is predicated on moral culpability and youthful offenders are less morally culpable for their crimes than are adults. ${ }^{115}$ The deterrence rationale fails because an impulsive adolescent who does not consider consequences and who is convinced of her own invincibility will be no more deterred by the possibility of the death penalty than she is by the risk of a life term in prison. ${ }^{116}$

As articulated by various Roper amici, the developmental deficiencies characteristic of juveniles have an even greater negative impact on the possibility of reaching a just result in a capital case because young people are more likely to be coerced or intimidated into making false confessions because of their immaturity. ${ }^{117}$

Even without reference to the characteristics shared by adolescents and the developmentally disabled, diverse voices speaking against imposition of the death penalty for juvenile defendants made several arguments about juvenile incapacity in their Roper amicus briefs. These organizations espoused a view of adolescents as incapable of possessing adult culpability for criminal activity or moral culpability sufficient to warrant a punishment of death. The ABA brief noted that "juvenile offenders are less mature, less experienced, less able to exercise good judgment and self-restraint, more susceptible to environmental influence, and limited in their ability to assist in their own defense." 118

In the same vein, the American Psychological Association ("APA") brief urged the Justices to recognize that young people take far more risks than adults and "undervalue the true consequences of their actions." 119

Similarly, as compared to adults, "studies show that adolescents are less likely to consider alternative courses of action, understand the perspective of others, or restrain impulses." 120

114 Brief of Amicus Curiae of the American Bar Association in Support of the Respondent, at 9-11, Roper v. Simmons, 543 U.S. 551 (2005) (No. 03-633) (citations omitted) [hereinafter ABA Brief].

$115 \mathrm{Id}$. at 12.

116 Id. at 11-12; see also APA Akron Brief, supra note 44, at 14-15 ("With regard to deterrence, capital punishment will have a questionable effect on adolescents as a group because they are more impulsive and less able to anticipate the consequences of their actions.").

117 ABA Brief, supra note 114; see also Brief of the Coalition for Juvenile Justice as Amici Curiae in Support of Respondent at 15, Roper v. Simmons, 543 U.S. 551 (2005) (No. 03633) (citations omitted) [hereinafter Coalition for Juvenile Justice Brief] ("Juveniles, like the mentally retarded, have many difficulties in all aspects of the legal process-beginning with the police interrogation. CJJ's research reveals that juveniles are more likely, because of their immaturity, to make a false confession.").

118 ABA Brief, supra note 114 , at 2 . Of course, the amici recognize that young people are not a monolith and that "some juvenile offenders deserve severe punishment for their crimes. However, when compared to adults, juvenile offenders' reduced capacity - in moral judgment, self restraint and the ability to resist the influence of others-renders them less responsible and less morally culpable than adults." Id. at 3.

119 APA Akron Brief, supra note 44, at 6-7.

$120 \mathrm{Id}$. at 7. 
The APA brief also claims that biological factors may explain the differences in cognitive ability between adults and adolescents, as the adolescent brain has not yet reached its adult form. ${ }^{21}$ While much work remains in the arena of brain development and adolescent decision-making capacity, the crux of this still developing research is that "in late adolescence, important aspects of brain maturation remain incomplete, particularly those involving the brain's executive functions." 122

At least one Roper' amicus also expressed concern that young people lacked the capacity to meaningfully participate in their own defense, thus leading to a denial of their Sixth Amendment right to counsel. ${ }^{123}$

Before its Roper decision, the Court had previously described the underlying premise of its juvenile justice jurisprudence as beneficent paternalism "in the sense of a caring, nurturing parent making decisions on behalf of a child who is not quite ready to take on the fully rational and considered task of shaping his or her own life." 124 The Justices went on to explain that society assumes that, as a collective, children "do not yet act as adults do, and thus we act in their interest by restricting certain choices that we feel they are not yet ready to make with full benefit of the costs and benefits attending such decisions." 125 Given this societal assumption, the Court found irony in the suggestion that these assumptions about differences in children versus adults could not be used to protect minors from imposition of the death penalty. For the sake of consistency, the Court felt compelled to determine that it is "likely cruel, and certainly unusual, to impose on a child a punishment that takes as its predicate the existence of a fully rational, choosing agent, who may be deterred by the harshest of sanctions and toward whom society may legitimately take a retributive stance." 126

In Roper, the Court continued to embrace a view of minors as developmentally incapacitated such that they are not eligible for the death penalty, even when they have committed atrocious crimes. Citing their own common sense

121 Id. at 9 ("Recent research suggests a biological dimension to adolescent behavioral immaturity: the human brain does not settle into its mature, adult form until after the adolescent years have passed and a person has entered young adulthood.").

122 Id. at 12; see also Coalition for Juvenile Justice Brief, supra note 117, at 9-10 (citing research indicating that the adolescent brain is not yet fully formed which contributes to adolescent "impulsivity and mood swings"); Feld, supra note 18, at 515 ("Neurobiological evidence suggests that the human brain does not achieve physiological maturity until the early twenties and that adolescents simply do not have the same physiologic capability as adults to make mature decisions or to control impulsive behavior." (citation omitted)); BARbara Strauch, The Primal Teen (2003).

123 Coalition for Juvenile Justice Brief, supra note 117, at 11 (citation omitted) ("The diminished capacity of juveniles directly affects their ability to communicate with and direct their counsel, as well as their faculty for making important trial and procedural decisions. Many adolescent defendants, because of their relationship with authority and their developmental process, either do not perceive their attorney as being on their side or fail to give their attorney information about the charges against them out of mistrust.").

124 Thompson v. Oklahoma, 487 U.S. 815, 825 n.23 (1988).

$125 \mathrm{Id}$.

126 Id. For a similar discussion of the inconsistency in the law's treatment of young people, see, American Bar Association Juvenile Justice Center, A Deadly Contradiction (January 2004), available at http://ccjr.policy.net/proactive/newsroom/release.vtml?id=35841 (describing the many provisions of state law treating minors differently than adults). 
as well as more scientific sources, Justice Kennedy, writing for the majority, describes three key differences between juvenile and adult offenders that support a conclusion that minor criminal defendants should not be grouped "among the worst offenders." 27

First, embracing the Scott and Grisso position on adolescent capacity, the Court explains that "as any parent knows and as the scientific and sociological studies respondent and his amici cite tend to confirm" adolescents are immature and more understandably irresponsible than adults are. ${ }^{128}$ Second, they are more inclined to act in the absence of clear thinking about consequences. ${ }^{129}$ Third, and finally, the Court observes that peer pressure is a greater risk for young people and that their characters are more malleable than those of adults. ${ }^{130}$ Thus, the Court explains that a young person's personality is more "transitory" than that of an adult. ${ }^{131}$

Taken as a whole, adolescent immaturity, susceptibility to peer pressure, and the malleability of personality make it difficult to label a young person as being among the worst class of criminal actors. ${ }^{132}$ In the words of the Court:

Their own vulnerability and comparative lack of control over their immediate surroundings mean juveniles have a greater claim than adults to be forgiven for failing to escape negative influences in their whole environment. The reality that juveniles still struggle to define their identity means it is less supportable to conclude that even a heinous crime committed by a juvenile is evidence of irretrievably depraved character. From a moral standpoint it would be misguided to equate the failings of a minor with those of an adult, for a greater possibility exists that a minor's character deficiencies will be reformed. ${ }^{133}$

Advocates and the Supreme Court believe that the bulk of adolescent defendants possess a diminished ability to appreciate the consequences of their actions and to avoid acting out in ways that are reckless and perhaps criminal. Further, even when they do become lawbreakers, it is likely that the non-conforming behavior of adolescents is fleeting and youthful offenders are more amenable than their adult counterparts are to attempts to correct their bad behavior. This reality means that young people accused of crimes are deserving of more leniency and protection than are adults who have committed crimes.

\section{True Conflict?}

Thus far, this article has highlighted three areas in which adolescent competence, or the lack thereof, determines a regime of legal rights available to young people. These areas are criminal culpability, healthcare decision-making, and the ability to form an attorney/client relationship. This section will focus primarily on the first two issues, which reflect the greater distance in the articulation of adolescent competence or incompetence.

127 Roper v. Simmons, 543 U.S. 551 (2005).

128 Id. at 569.

129 ld. (citations omitted).

130 Id. at 570 (citations omitted).

131 Id.

132 Id.

133 Id. 
When viewing the issue of competing views of competence through the lens of the Supreme Court, one finds a thread of continuity to an extent that is not true of the advocates with whom this article concerns itself. From the perspective of the Supreme Court, young people are consistently flawed and generally immature whether they are committing capital crimes or seeking to terminate an unwanted pregnancy. The language used by the Court in cases dealing with adolescent competence in these two arenas is strikingly similar even if the outcomes may initially appear contradictory.

In its abortion jurisprudence, while extending some protection to adolescent women seeking to end their pregnancies, the Supreme Court does not stake a claim for the maturity of young women. Instead, the justices who support a young woman's right to seek an abortion without the knowledge or consent of her parents do so based on several rationales including an assertion that abortion, like the death penalty, is different and therefore requires some bending of the general rule on parental consent for healthcare for minors. ${ }^{134}$ In the words of the Court:

The abortion decision differs in important ways from other decisions that may be made during minority. The need to preserve the constitutional right and the unique nature of the abortion decision, especially when made by a minor, require a State to act with particular sensitivity when it legislates to foster parental involvement in this matter. ${ }^{135}$

The Court carefully avoids making a general pronouncement on adolescents and limits its decision to abortion to the extent that the decision seems to devalue the primacy of the parental role in raising children.

In the end, the Court's abortion decisions rest on an understanding of young people in general and young women in particular as generally lacking in mature decision-making ability. Thus, it is appropriate and constitutionally acceptable for states to require some measure of adult supervision of the abortion decisions made by young women. They can do this either by mandating parental involvement or requiring that a judge determine that the minor is mature or that, even if she is immature, an abortion is in her best interest.

In the criminal context, the Court's Roper decision stands for the proposition that people under the age of eighteen, as a class, lack the criminal competence that would allow for the imposition of a death sentence. ${ }^{136}$ As described in an earlier section of this paper, juvenile justice advocates claim that many adolescents lack the developmental skills to warrant criminal culpability in general. ${ }^{137}$ Even if a young person's actions warrant a finding of criminal culpability, the justice system should not subject young offenders to more severe sanctions such as incarceration in adult prisons, life sentences, or the death penalty. ${ }^{138}$ According to these advocates, the law should treat young criminal defendants differently for a variety of reasons including their greater potential

\footnotetext{
134 Bellotti v. Baird, 443 U.S. 622, 642-43 (1979).

135 Id.

136 Roper v. Simmons, 543 U.S. 551, 574 (2005).

137 See supra notes 65-97 and accompanying text.

138 See discussion supra notes 98-133 and accompanying text.
} 
for rehabilitation, their still developing brains, their susceptibility to peer pressure, their impulsiveness, and their reckless nature. ${ }^{139}$

Of course, to say that the Court is consistent is not to say that the Justices are right. There is little to no value in having a consistent position if that position does not comport with reality. Thus, the section that follows offers another way to conceptualize adolescent competence that can be consistently applied across areas of law and that acknowledges the complexity of the competence inquiry as well as its shifting terrain from person to person and from decision to decision.

\section{A. Agreeing to Disagree}

Advocates in the criminal arena and the healthcare decision-making arena agree in some ways. Both sides agree that it is useful and, perhaps, even necessary to turn to developmental psychology ${ }^{140}$ to evaluate how to create a legal regime, whether criminal or healthcare related, that properly deals with the needs and issues of adolescents. ${ }^{141}$ Both sides also seem to agree that there are differences between adolescents and adults for which the law can and should compensate in the context of making policy for healthcare or criminal justice.

While advocates for adolescents may agree that young people are in a unique stage of life that policies meant to govern their actions should reflect, it is the case that advocacy groups do not necessarily agree on the consequences of these differences or the full extent to which they exist. When the two groups assert conflicting understandings of adolescent competence, they potentially weaken the other's cause with the result that both sides suffer.

Viewing the claim of a single organizational actor, one can see how advocates can even contradict their own work. In an amicus brief submitted in an abortion case, the APA and others explained that competent decision-making depends on "social and personality development including the development of personal values, identity, autonomy, and the ability to resolve social dilemmas." 142 The amici informed that Court that:

Research in social and personality development contradicts the stereotype of adolescence as a period when young people are paralyzed by a struggle for identity, social confusion and rebellion against parents. In fact, by middle adolescence (age 14-15) young people develop abilities similar to adults in reasoning about moral dilemmas, understanding social rules and laws, reasoning about interpersonal relationships and interpersonal problems, and reasoning about custody preference during parental divorce. By middle adolescence most young people develop an adult-like identity and understanding of self. Furthermore, the majority of adolescents do not repudiate parental values, but incorporate them, during their search for autonomy. Thus, by age 14 most adolescents have developed adultike intellectual and social capacities including specific abilities outlined in the law as necessary for understanding treat-

139 See discussion supra notes 65-97 and accompanying text.

140 Developmental psychology "studies changes across the life-cycle in physical, social, intellectual, and emotional development, and, from its earliest foundation, has posited that young people move through a sequence of stages in legal reasoning and moral decision making." Feld, supra note 18, at 502.

141 See, e.g., Britner et al., supra note 3, at 40; Scott \& Grisso, supra note 73.

142 APA Akron Brief, supra note 44. 
ment alternatives, considering risks and benefits, and giving legally competent consent. $^{143}$

Several years later, in a case seeking an end to the juvenile death penalty, the APA joined an amicus brief that made several observations about adolescent immaturity noting that adolescents are greater risk takers than adults and that young people do not have a full grasp of the consequences of their actions. ${ }^{144}$ Rather, as described earlier in this article, adolescents "as a group, often value impulsivity, fun-seeking, and peer approval more than adults do." 145 Young people, apparently, are also "less likely to consider alternative courses of action, understand the perspective of others, or restrain impulses."146

If the same collection of people can offer such competing images of young people, all supported by research, it is not surprising that the law struggles with how best to understand adolescent patients and defendants. The fact that those on both sides, all of whom seek to do what is best for young people, assert such disparate positions on adolescent competence is of no great surprise given the overall legal and political climate in which these advocates find themselves. In no small part, the work of advocates reflects a reasoned response to the rhetoric of their political opponents whom they oppose. In the juvenile justice arena, advocates for young people battle a system that dangerously and inaccurately assumes "that there are no psychological differences between adolescent and adult offenders that are important to criminal responsibility or to participation in adult criminal proceedings." 147 To accept this regime is to accept that there is no reason to treat a fourteen-year-old criminal differently than a forty-yearold criminal-a position that leaves young people exceedingly vulnerable to abusive and unjust treatment at the hands of the legal system.

Those who advocate for an expanded understanding of adolescent competence in healthcare do so in response to arguments of incapacity that would leave young people subject to the desires of their parents or caretakers when making incredibly intimate and personal decisions about a range of healthcare issues, including abortion. Advocates for young people in the healthcare arena use available data, limited though it may be, to argue that the law's treatment of young people for purposes of making autonomous healthcare decisions is problematic and results in a regime that works to the detriment of young people. ${ }^{148}$ Significant literature from healthcare providers and professional organizations for these providers supports a view that legal decision makers have unfairly characterized adolescents collectively as incompetent. ${ }^{149}$

In their work, Scott and Grisso take specific issue with the claim that from about the age of fourteen, adolescent decision-making capacities rival those of adults thus justifying greater self-determination rights for young people includ-

${ }^{143}$ Id.

144 Coalition for Juvenile Justice Brief, supra note 117, at 9.

145 APA Akron Brief, supra note 44 , at 7.

146 Id.

147 Scott \& Grisso, supra note 73, at 151.

148 See, e.g., Hartman, supra note 3.

149 See Society for Adolescent Medicine, Access to Healthcare for Adolescents: A Position Paper of the Society for Adolescent Medicine, 13 J. OF Adolescent Health 162 (1992); Pediatrics Comm., supra note 28, at 317. 
ing the right to make informed and competent decisions about their own healthcare. ${ }^{150}$

In rejecting the usefulness of the above-described analysis for purposes of juvenile justice, Scott and Grisso write:

Together this scientific research and theory support the claim that adolescents are more competent decision-makers than has been presumed under paternalistic policies, but that scientific evidence for the claim that their cognitive decision-making capacity is comparable to that of adults is unclear. . . Further, the studies that support the claim of competence are small and mostly involve middle class subjects of average intelligence. Only a handful compares the decision-making of minors with that of adults. Finally, the studies of adolescent decision-making have been conducted in laboratory settings in which the decision is hypothetical and "pre-framed" in the sense that all relevant information is provided to the subjects. This format yields little useful data about how decisions are made in informal unstructured settings (such as the street), in which decision-makers must rely on their own experience and knowledge in making choices. Moreover, research offers little evidence of how minors may function relative to adults in stressful situations in which decisions have salience to their lives. ${ }^{151}$

Therefore, even while conceding that there is some authority behind claims that those in mid-adolescence can reason and understand in adult ways, the authors warn of extreme variability in the existence and employment of these capacities. ${ }^{152}$ They suggest that the value of structured studies on adolescent decision-making involving posing hypothetical dilemmas "may be more useful in shedding light on questions about competence to stand trial than on cognitive capacity as it affects choices relevant to criminal conduct." 153

This critique is at the core of the conflict between advocates that forms the basis for this article. Disagreements about the import of research combined with different political agendas leads to fracture among groups that do not nec-

150 Id. at 159. (citing Gary B. Melton, Toward "Personhood" for Adolescents: Autonomy and Privacy as Values in Public Policy, 38 Aм. Psychologist 99 (1983); Patricia King, Treatment and Minors: Issues Not Involving Lifesaving Treatment, 23 J. FAM. L. 241, 25253 (1985); Stephen B. Billick, Developmental Competency, 14 Bull. AM. ACad. PsychiaTRY \& L. 301, 306-08 (1986); Brief for Am. Psychological Ass'n as Amicus Curiae supporting Appellees, Hodgson v. Minnesota, 497 U.S. 417 (1990) (No. 88-805) (arguing against parental notification of adolescent abortion decision, in part on ground that adolescents have similar decision-making competence); Brief for Am. Psychological Ass'n as Amicus Curiae supporting Appellees, Zbaraz v. Hartigan, 484 U.S. 171 (1987) (No. 85-673).

151 Scott \& Grisso, supra note 73 , at 159-60 (citations omitted).

152 Id. at 160 (citations omitted).

153 Id. As another author explains:

Some of the developmental changes parallel the imputations of responsibility associated with the common law infancy defense, and by mid-adolescence most youths acquire cognitive reasoning capacity roughly comparable to that of adults. When, for example, youths make informed consent decisions for psychotherapy or medical treatment, few bases exist to distinguish between mid-adolescents and adults in terms of the information used or the reasoning processes employed. Studies that equate adolescent and adult cognitive ability derive primarily from informed consent research that emphasizes subjective preferences. But the ability to make hypothetical decisions under structured laboratory conditions with complete information differs significantly from the ability to exercise mature judgment when equipped with incomplete knowledge, under stressful conditions, and with real-life consequences.

Feld, supra note 18, at 504 (citations omitted). 
essarily want to harm each other. For those who find merit in protecting juveniles from adult criminal sanctions and in extending greater healthcare decision-making rights to youth, and I suspect that there is much overlap between the two, it behooves us to find a plausible way to make sense of both positions.

It is not given that disagreeing about the pace at which young people develop means that these two groups of advocates are fundamentally at odds. However, as one author wrote:

[A]s the legal system recognizes more and more autonomy rights belonging to teenagers in a wide range of non-criminal matters, it inevitably creates a dissonance with the idea that in the criminal sphere, paternalism is still appropriate. This dissonance is evident at both ends of the political spectrum. The stereotypical liberal calls for expanded recognition of adolescents' rights in a wide range of civil contexts, while defending a juvenile justice system that is based on the premise that an adolescent's choice to commit a crime is rendered less culpable because of the adolescent's age. In contrast, the stereotypical conservative will call for full application of adult penalties to adolescent criminals, but will deny the right of teenagers to make decisions that must be respected by the law in a wide variety of other contexts, presumably on the grounds that one so young cannot be fully capable of making such significant choices. ${ }^{154}$

The question then becomes whether it is possible to simultaneously embrace the arguments made by juvenile justice advocates and healthcare decision-making advocates or if the law must pick one set of arguments over the other.

\section{Reconciling Dueling Visions of Adolescents}

In his article that reflects on cognitive dissonance in the law's understanding of adolescent autonomy, Professor Donald Beschle opines that one way to reconcile conflicting views of adolescents in criminal law and abortion decision-making is to believe "that competence varies in different contexts, and the ability to make a responsible decision as to things like health care and reproduction issues is noticeably different from the ability to choose to obey or not obey the criminal law." 155 He then explores the various difficulties that may arise from taking such a position, though he does not delve into whether that position is even supportable. This section takes seriously the idea that the context of decision-making is relevant to a young person's competence to make a given decision. The core claim is that decision-making in different contexts is so qualitatively dissimilar that it is not incongruous to find that the same individual's decision-making abilities may be sufficient to support autonomous decision making in one realm but insufficient to support a finding of autonomous decision-making in a distinct set of circumstances.

It is an accepted principle among many authors that competence is not a rigid concept and that, say in the midst of a physician-patient relationship, a patient may be competent to make some treatment decisions and not others. For instance, a physician might be comfortable honoring a patient's wish to not

154 Beschle, supra note 1 , at 67.

155

Id. at 103 . 
take an antibiotic to stave off a minor infection, but might balk at that patient's decision to refuse a life-saving blood transfusion. The degree to which the healthcare provider would want to ensure decision-making capacity would be enhanced in the latter case. While decision-making capacity might be found when refusing antibiotics, the provider would not necessarily be mistaken in finding that the patient did not have capacity to refuse the transfusion that would save her life. The conflicting findings would presumably reflect the patient's deficiency in one of the hallmarks of decision-making capacity namely her ability to comprehend relevant information, contemplate choices, and communicate a decision. ${ }^{156}$

A determination of a lack of decision-making capacity when the patient refused the blood transfusion might logically flow if the patient, in discussions with her healthcare provider, clearly indicated that she did not comprehend the seriousness of her illness. Likewise, a lack of decision-making capacity might exist if the patient was in such a state of deterioration that she could not communicate a treatment choice to her healthcare provider. In either of these circumstances, the healthcare provider would be justified in believing that the patient lacked decision-making capacity and would therefore be found legally incompetent to make treatment decisions for herself.

When discussing questions of competence and young people, it is equally valid to believe that determinations of competence cannot be rigid. As described by one commentator:

Competence is not an "all or nothing" quality; it develops gradually, particularly if the child has opportunities to try out budding skills. A child does not always have a general level of competence. Rather, a child may be competent in one area, but not in another, and may be competent to take on part of a given task, but not the whole. $^{157}$

This is so in part because of the shifting terrain upon which an individual stands when making various decisions.

In their piece on the juvenile justice system and adolescent criminal responsibility, Scott and Grisso explore the possibility that decision-making capacity varies in part based on the circumstances in which a decision takes place. The authors critique available scientific literature on adolescent decision-making by highlighting the fact that the highly structured setting of such research perhaps makes it more appropriate for understanding the decisionmaking capacities of young people in the context of court hearings rather than the off-the-cuff decision-making of "the street."158 In other words, how adolescents make decisions in informal settings in conjunction with peers may be very different than how those same young people embark on decision-making in more organized, formal, and monitored settings such as a courtroom or a physician's office.

In a critique related to that offered by Scott and Grisso, those reporting on their own research finding comparable levels of competency to make healthcare-related decisions among adults and young people fourteen and older note

156 Hastings CTR., supra note 4.

157 Mallfrid Grude Flekkøy, Psychology and the Rights of the Child, in CHILdREN AS EQuals (Kathleen Alaimo \& Brian Klug, eds., 2002).

158 Scott \& Grisso, supra note 73. 
that "[t]he generalizability of these finding may be somewhat tempered by the fact that subjects were 'normal,' white, healthy individuals of high intelligence and middle-class background and that the situations they considered were hypotheticals." 159 Even accepting that the findings of these authors may not be applicable to all young people, the fact that a sizeable portion of young people possesses high levels of competence cuts in favor of a more nuanced approach to understanding adolescent decision-making capacity in both criminal and healthcare law.

The law, in many respects, has taken the position that, as Scott and Grisso assert in the criminal context, "because of inexperience and immature judgment, youths will make mistakes during this period"160 and the best way to protect young people from the consequences of such mistakes is to assume their incompetence. But the decisions being made by young people who choose to engage in criminal activity and those being made by young people seeking out healthcare are substantially different in kind and character. Thus, when viewed as a product of the circumstances under which decision-making takes place, a bad decision about engaging in criminal activity might largely reflect areas in which adolescents are deficient in the ability to make reasoned decisions. In contrast, a decision to pursue a certain type of healthcare treatment might reflect the best and highest level of that young person's decision-making capabilities.

To understand how this could be the case, imagine two scenarios patterned after actual Supreme Court cases. In the first, a seventeen-year-old girl stands accused of committing a robbery and murder with two friends, one fifteenyears-old and the other sixteen-years-old. For several days before committing the crime, the seventeen-year-old and her co-conspirators engaged in lengthy discussions about choosing a victim and how to make their endeavor "successful." The instigator of the crime believed, erroneously, that, even if caught, she and her companions could not be tried as adults or sent to an adult facility because they were all under the age of eighteen. The motivation for committing the crime was the young woman's desire to purchase a used car.

Assuming normal development and a lack of identifiable mental health issues, it is quite likely that this young woman would be found criminally culpable for any robbery and murder ensuing from her plan to engage in this kind of activity. From the limited facts presented, she planned her activity and she intended all of her actions even if she did not wholly appreciate the extent of the consequences for herself and her companions. However, one could make a strong argument that even if criminally culpable, her decision to engage in this activity reflects the most diminished level of decision-making capacity among adolescents. Specifically, while she intended to commit a crime and was successful in doing so, the quality of that decision-making, not just the ultimate decision itself, was poor. Though she did discuss her plans to commit a robbery and murder, she did so only with her peers. She engaged in planning, thus the crime was not an impulse, but her reflection on consequences for her vic-

159 Weithorn \& Campbell, supra note 29, at 1596.

160 Scott \& Grisso, supra note 73. 
tim, herself, and her companions evidences recklessness and a dearth of future thinking.

It is in this kind of scenario that concerns about impulsivity, lack of forethought, diminished ability to empathize, inability to imagine a broad range of options, and lack of knowledge and experience may be most prominent and lead to horrible consequences. These are the on the street decisions about which Scott and Grisso raise a red flag because in these circumstances young people engage in decision-making without the type of support that would allow for more complex thinking leading to better decisions. In these settings, an adolescent tendency to consider a minimum number of options and consequences $^{161}$ may rear its head. In these "unstructured informal settings, where information is not provided, and individuals must make choices based on their own knowledge and experience," 162 young people are at a decided decisional disadvantage. Their lack of life experience, penchant for risk-taking, deficient focus on the future, and weakness for peer influence will all serve them poorly in this loose setting ${ }^{163}$ and will severely diminish the quality of an adolescent defendant's decision-making.

While it is possible that some young people engage in extended periods of speculation before committing a crime and enlist the advice of trusted adults in making decisions to commit crimes, it seems likely that this is frequently not the case. Instead, much of adolescent crime reflects impulsiveness, the tug of peer pressure, and a failure to seriously contemplate the potential consequences flowing from the criminal activity. ${ }^{164}$

As Feld explains:

Unlike informed consent studies conducted under laboratory conditions, in less-structured, real-life circumstances, adolescents simply may know less about risks than do adults. They may perceive fewer alternative options than do adults. Young people may discount negative future consequences because they have more limited experience. Disadvantaged youths, in particular, may feel a sense of "futurelessness," fatalism, and despair, which inclines them to discount future consequences even more than do other teenagers. ${ }^{165}$

Contrast the context of an adolescent making a Roper-like decision to engage in criminal behavior, with the decision of a young woman to end a pregnancy without the knowledge or consent of her parents. In this second scenario, the young person will again be called upon to use various forward thinking capacities to evaluate the appropriateness of her decision for herself and, perhaps, for others around her such as her parents, the biological father of the child, and the future child. This would implicate concerns about the young person's ability to think in critical ways about the future and imagine outcomes. However, unlike an individual making decisions on the street about engaging in crime, this young woman will not have to act alone or only with the benefit of discussions with peers who may be equally deficient in the experience and

\footnotetext{
161 Id. at 165 (citations omitted).

162 Id. at 164 (citations omitted).

163 Id.

164 See, e.g., Coalition for Juvenile Justice Brief, supra note 117, at 24-29.

165 Feld, supra note 18, at 509-510 (citations omitted).
} 
knowledge needed to make this decision well and who may also be prone to acting impulsively.

Most young women, even without the prodding of a parental notification statute, will discuss a decision to have an abortion with a parent. ${ }^{166}$ It is highly unlikely that most young people discuss plans for criminal activity with their parents before committing crimes. Even those young women who choose not to share information about their pregnancy with their parents will necessarily have to engage with an adult professional who will provide that care, as is true of any young person seeking services from a healthcare provider. The young patient will participate in a process meant to ascertain whether her consent is knowing, voluntary, and intelligent. ${ }^{167}$ During this informed consent process, the patient's healthcare provider will inform her of her medical diagnosis, the available treatments and alternatives, and the risks and rewards of her decision to pursue a particular course of treatment or no treatment at all. ${ }^{168}$ She will, theoretically, have an opportunity to ask questions before making a final decision and may even have a significant period in which to contemplate her decision before making a final choice. As she seeks to make a decision, she will have a knowledgeable adult at her disposal from whom she can seek advice and counsel about any given course of action. While it may still be possible for a young person to make decisions that are "erroneous," those decisions will, in large part, come after some period of reflection and deliberation that one does not necessarily expect to take place before a decision to engage in criminal behavior.

Even more importantly, in the context of a healthcare provider/patient relationship, even without referring to the legal regime that allows parents to make most healthcare decisions for young people, the healthcare provider has an obligation to seek substituted consent for treatment when a patient appears incompetent to make decisions. ${ }^{169}$ Further, in extreme cases where there is a dispute between provider and patient about a correct treatment path, the possibility of resort to court action exists. ${ }^{170}$

It is necessary to believe in adolescent competence as an elastic concept in order to simultaneously believe that one can be competent to commit a crime, lack the requisite competence to warrant imposition of the harshest penalty available for that crime, but possess sufficient competence to direct one's own

166 APA Akron Brief, supra note 44 (citing Aida Torres, Jacqueline Darroch Forrest \& Susan Eismann, Telling Parents: Clinic Policies and Adolescents' Use of Family Planning and Abortion Services, 12 Fam. PlanN. Persp. 284, 287-90 (1980); Freddie Clary, Minor Women Obtaining Abortions: A Study of Parental Notification in a Metropolitan Area, 72 AM. J. Pub. Health 283, 284 (1982); Raye Hudson Rosen, Adolescent Pregnancy DecisionMaking: Are Parents Important?, 15 AdOLESCENCE 43, 44 (1980)).

167 Am. Medical Ass'N, Informed Consent, www.ama-assn.org/ama/pub/category/4608. html (last visited May 16, 2006).

168 Id.

169 Id. ("Patients generally have a moral and legal right to refuse proposed medical intervention, except when the patient has diminished decision-making capacity or must undergo legally authorized 'involuntary' treatment.").

170 For cases where healthcare providers have been involved in court disputes over appropriate healthcare treatment for a minor patient, see, e.g., In re E.G., 549 N.E.2d 322, 325 (IIl. 1989); Cardwell v. Bechtol, 724 S.W.2d 739 (Tenn. 1987); In re Swan, 569 A.2d 1202 (Me. 1990). 
legal representation and make healthcare decisions. The fluidity of this concept allows relevant parties to judge competence in a consistent manner across different types of decision-making. While there is one overarching understanding of adolescent competence that understanding allows for a nuanced and contextspecific determination of whether youthful incapacity has interfered with a young person's ability to make carefully considered adult-like decisions.

Some might argue, unpersuasively, that the outcome of any given legal regime should determine whether it is appropriate. This type of ends-focused thinking allows those who espouse it to pick a legal regime that inexorably leads to a desired consequence. ${ }^{171}$ In such a case, the possibility of fewer young people being confined to adult prisons or subjected to the death penalty would justify a regime of presuming incompetence for adolescents in criminal law. This is a positive outcome only to the extent that one believes that young criminals should be treated less harshly than their adult counterparts. An outcome oriented argument might also lead to a conclusion that a competence presumption is appropriate in the context of healthcare decision-making because it will avoid the risk of young people eschewing necessary care for fear of being forced to discuss difficult issues with parents or other adult caretakers. Again, this outcome makes sense only to the extent that one believes that there are instances when parental control over young people is inappropriate or dangerous.

Rejection of a system created simply to reach a desired end in a particular politically charged issue does not conform to how many assume that a properly configured legal system should function. As Professor Beschle writes:

It would be difficult to deny that American law is largely shaped by a pragmatic concern for achieving outcomes thought desirable by majorities or influential minorities, regardless of whether these outcomes can all be reconciled with each other, let alone with some overriding philosophy. Still, most of those involved in the legal system at least like to think of themselves as consistently applying a coherent set of values. To simply disregard the dissonance created by inconsistent treatment of adolescent autonomy would be to ignore something significant. ${ }^{172}$

By focusing on the nature of development as opposed to the outcome of a chosen legal regime, it is possible to avoid some pitfalls. Though there may be disagreement about how to interpret available science, it is indisputable that there are consequential differences between adults and adolescents when it comes to making decisions. Some of these differences are strictly reflections of time (i.e., adolescents have not lived as long and presumably have had fewer life experiences to aid them in the process of making informed decisions about their own conduct). Other differences may be a reflection of biology. In either case, the result is that context is critical for determining adolescent capabilities. A young person's decision-making skills can be enhanced when coupled with opportunities to engage with responsible adults before making a decision

171 Beschle, supra note 1, at 102. ("Of course, the premise of this Article, that both a rejection of paternalism and support for the value of logical consistency are widely shared in the legal and political system, may simply be incorrect. If so, both liberals and conservatives may merely be acting as consequentialists in pursuit of different values. There may, then, be no real dissonances to resolve".).

172 Id. at 103. 
whereas the deficiencies in adolescent decision-making are brought painfully to light in other circumstances that play to the weakest elements of the adolescent experience.

In the end calculus, it is probably the case that all competence evaluations, whether in the context of criminal law or healthcare decision-making, should be conducted on a case-by-case basis rather than creating a bright line rule that inevitably goes too far in some cases and not far enough in others. While bright line rules create ease of application, they do so at the expense of those who are exceptions. In both healthcare decision-making and criminal law, young people are well served by a view of adolescent competence that accepts the strong possibility of adult-like decision-making while remembering that some meaningful differences between the old and the young do exist and should be accounted for by the legal system.

Were the Supreme Court to abandon its baseline assumption of adolescent incapacity or incompetence, it does not then follow that its death penalty jurisprudence would be any different, though it is quite likely that its abortion jurisprudence would shift. For instance, in a case like Roper, the Court's focus would still be on the developmental capacity of young people and the literature on young people and criminal activity would still be quite relevant. However, the inquiry would focus much more squarely on two issues: (1) the context in which criminal decisions get made, and (2) how this context impacts whether a minor criminal defendant can be said to be criminally culpable and the extent to which opportunities for rehabilitation are more available for young people whose personalities, and thus their futures, are more malleable.

For abortion cases, a shift in the Supreme Court's developmental analysis of young people would reinforce a young woman's right to terminate a pregnancy and likely place that right on par with adult women who are pregnant and contemplating abortion. Again, an evaluator would focus on the extent to which the context in which a young woman makes an abortion decision compensates for potential developmental deficiencies that might caution against allowing young women to make independent abortion decisions.

\section{Conclusion}

There is a discrepancy in the view of adolescent competence espoused by two camps of advocates for young people. The goal of highlighting these competing claims is not to suggest that either is not supportable, relevant, or worthy of respect. Rather, the hope is that the two can co-exist without causing damage to each other. Advocates can certainly make claims about adolescent competence and decision-making capacity, or a lack thereof, but they must be cognizant of potential inconsistencies in those claims and be prepared to either accept that inconsistency or explain it away. Simply assuming that the masses will blithely accept competing arguments about adolescent competence in different areas of the law without some explanation of what accounts for those difference is a mistake.

It is not a given that this article's argument based on the importance of context for purposes of evaluating the decision-making skills of a given young person will be sufficient to convince the skeptical. However, the hope is that 
this article raises a red flag about the ways in which advocates undermine each other's work and offers some worthwhile ideas to help knit a more coherent narrative about adolescents and the law. 